
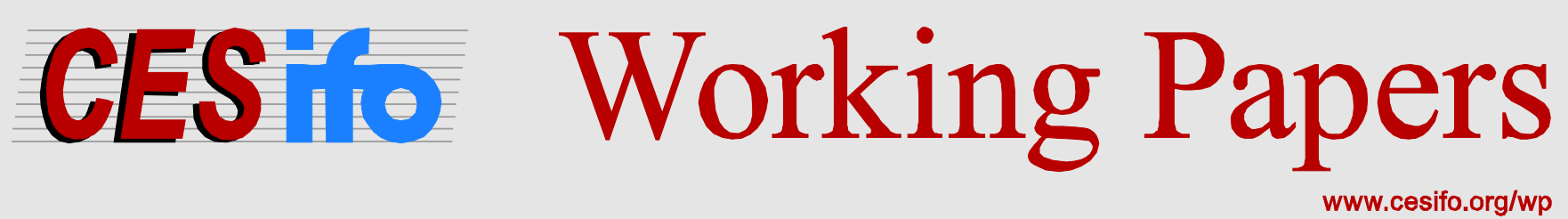

\title{
Divided We Reform? Evidence from US Welfare Policies
}

\author{
Andreas Bernecker
}

\section{CESIFO WORKING PAPER NO. 4564 \\ CATEgORY 2: Public CHOICE \\ JANUARY 2014}
An electronic version of the paper may be downloaded
- from the SSRN website: Www.SSRN.com
- from the RePEc website: Www.RePEc.org
- from the CESifo website: www.CESifo-group.org/wp

\section{CESifo}




\title{
Divided We Reform? Evidence from US Welfare Policies
}

\begin{abstract}
Divided government is often thought of as causing legislative deadlock. I investigate the link between divided government and economic reforms using a novel data set on welfare reforms in US states between 1978 and 2010. Panel data regressions show that under divided government a US state is around $25 \%$ more likely to adopt a welfare reform than under unified government. An analysis of close elections providing quasi-random variation in the form of government and other robustness checks confirm this counter-intuitive finding. The empirical evidence is consistent with an explanation based on policy competition between governor, senate, and house.
\end{abstract}

JEL-Code: D720, D780, H110, H750.

Keywords: divided government, legislative deadlock, policy innovation, US welfare reform, policy competition.

\author{
Andreas Bernecker \\ Department of Economics and Collaborative Research Center \\ "Political Economy of Reforms" (SFB 884) \\ University of Mannheim, L7, 3-5 \\ Germany - 68131 Mannheim \\ andreas.bernecker@gess.uni-mannheim.de
}

This version: December 10, 2013

First version: December 2012

I thank the International Institute of Public Finance for awarding an earlier version of this paper the "Peggy and Richard Musgrave Prize” for the best paper presented by an economist under the age of 40. For guidance and constant advice, I am grateful to my advisors Eckhard Janeba and Christina Gathmann. For helpful comments and discussions, I thank Thushy Baskaran, Johannes Becker, Serra Boranbay, Pierre Boyer, Thomas Bräuninger, Ralf Brüggemann, Micael Castanheira, Antonio Ciccone, Valentina Corradi, Marc Debus, Georgy Egorov, Tore Ellingsen, Olle Folke, Ronny Freier, Clemens Fuest, Vincenzo Galasso, Hans Peter Grüner, Mark Hallerberg, Zohal Hessami, Björn Tyrefors Hinnerich, Magnus Johannesson, Leo Kaas, Georg Kirchsteiger, Thomas König, Miklos Koren, Christian Lessmann, Erik Lindqvist, Johannes Lindvall, Alessandro Lizzeri, James Lo, Andreas Madestam, Francois Maniquet, David Mayhew, Claudio Michelacci, Sten Nyberg, John Nye, Torsten Persson, Per Pettersson-Lidbom, Justin Phillips, James Poterba, Niklas Potrafke, Panu Poutvaara, Sven-Oliver Proksch, Steffen Reinhold, Johanna Rickne, Mark Schelker, Mary Shirley, Albert Solé-Ollé, Thomas Stratmann, David Strömberg, Carsten Trenkler, George Tsebelis, Heinrich Ursprung, Daniel Waldenström, AndreaWeber, Richard van Weelden, Galina Zudenkova, and many others. I also thank seminar participants at University of Mannheim, Stockholm University, Stockholm School of Economics, European Central Bank, Uppsala Center for Fiscal Studies, Lund University, University of Konstanz, Ifo Institute Munich, ZEW Mannheim, and at numerous conferences and workshops. All errors are my own. Funding by the DFG through SFB 884 is gratefully acknowledged. 


\section{Introduction}

"Now, hug a Republican", the Economist told President Obama via the title of its November 10th issue after he had won reelection in 2012 (The Economist (2012)). The newspaper referred to the fact that Democrat Obama would again have to deal with a Republican majority in the House of Representatives. As before the election, government would be divided. Divided government means that the President is faced with a majority of another party in at least one of the two chambers of Congress. Usually, it is argued that this hinders legislative productivity since the government cannot get its bill proposals through Congress without getting the consent of the opposition party. The legislative majority may even decide to block any relevant initiatives taken by the President resulting in complete legislative deadlock. Similar deadlock arguments are often also made with respect to comparable situations of partisan divide in other countries. This paper systematically analyzes this issue for the US states level by answering the following question: Is it really true that actual political reforms are less likely under divided as opposed to unified government? - I show that the contrary is in fact the case.

The standard deadlock argument made with respect to divided government is that differing partisan dominance of different institutions leads to a lower propensity to reform since the different parties have to agree on how to deviate from the status quo. This intuition has been theoretically formalized by George Tsebelis in his seminal work on veto players (Tsebelis (1995), Tsebelis (2002)): The more veto players have a say in policymaking, the less likely are reforms changing the status quo. Similarly, Howitt and Wintrobe (1995) show in a theoretical model how political inaction may result when both parties have power and competition is stiff. Along with conventional wisdom, theory thus clearly predicts that one should expect fewer reforms under divided government compared to unified government. But is this the whole story? Maybe different party dominance of different governmental bodies enhances policy competition between them leading to more reforms in the end? This is why this paper sets out to empirically assess reform adoption by divided versus unified governments.

I investigate whether welfare policies are more likely to be reformed under divided or under unified government using novel data from the US states level from 1978 to 2010. During this period of time, more than one half of all US state governments were divided. Welfare politics is an interesting case to look at for at least three reasons. First, welfare is one of the policy areas most central to economics and also among the largest budget items both at the US federal level and at the state level (US Government Spending (2013)). Second, during the time span analyzed in this paper the US Welfare Reform was at the center of the public debate since it represented the largest shift in welfare politics since the New Deal in the 1930s. US states reformed important elements of the welfare system such as work requirements, sanctions, and time limits. However, despite the large public and political interest in these reforms and a large policy evaluation literature on the topic, the political economy aspect is heavily underresearched. Third, welfare politics is a perfect field for the analysis of the effects of divided government since, along with the governors, state legislatures played a key role in the process. If divided government indeed leads to political parties blocking each other, one should definitely observe this for a very partisan issue such as welfare politics. Given all this, this paper analyzes a rich data set on welfare 
reforms at the US state level constructed from several different sources. Welfare policy changes for all US states are coded on a yearly basis and a wide range of demographic, political, and ideology controls are included. The resulting novel data set gives a comprehensive overview of welfare reform activity in US states between 1978 and 2010.

Different measures of welfare reform are then used as dependent variables in panel data regressions. The main explanatory variable is divided government. By divided government I mean that the state governor is confronted with a majority of legislators of the other party in one or both of the chambers of the state legislature. Including fixed effects allows within-state identification, i.e. the analysis compares the reform effects of a unified government in Wisconsin to a divided government in Wisconsin (and not a unified government in Wisconsin to a divided government in New York). I show that under divided government a US state's probability to implement a welfare reform is actually between 5 and 10 percentage points higher than under unified government. The size of this effect amounts to between 20 and $50 \%$ of the unconditional probability of a US state to implement a welfare reform between 1978 and 2010. The effect is highly significant and stable across specifications. This result is in stark contrast to conventional wisdom and standard theory.

To check the robustness of my finding, I explore potential issues of omitted variable bias, measurement of the dependent variable, reverse causality, differential treatment effects, and estimation technique. To avoid omitted variable bias, I test the inclusion of standard demographic controls, variables related to welfare reform and welfare state crisis, political and ideological controls. I also include year fixed effects and control for a state's reform history and reform spillovers across states. None of these controls affects the result. I also show that the effect does not depend on the way welfare reform is measured in the data and does also hold when considering only large reforms, for example. To take care of reverse causality and further potential endogeneity concerns, I focus on close elections providing quasi-random variation in the type of government. Still, I find the positive and significant effect of divided government on reform adoption. An analysis of different subsamples allows investigating differences in the effect, e.g. for Southern versus non-Southern states. Finally, also with respect to employing different estimation techniques the result is very robust. Divided governments are more likely to reform than unified governments.

Why do divided governments reform more? - I suggest policy competition between governor, senate, and house as potential explanation. It is well known that these three institutions typically engage in stiff competition with each other (e.g. Rosenthal (2009), p. 197). Under different partisan dominance this competition may be even more intense. The relevant difference between unified and divided government is that under the latter also the opposition party has agenda setting power: By passing bills the opposition party dominating a legislative chamber can confront the governor with policy issues. Policy competition between the actors may arise and more innovative policies may be implemented in the end. In some cases, the opposition leader may even want to qualify as able future governor in the eyes of the voters by passing innovative reform bills.

An empirical analysis based on different types of divided government provides evidence that is consistent with the policy competition theory. It is also supported by welfare reform case 
studies. For example, in Wisconsin Democrats having the majority in the state legislature suggested even more drastic welfare reforms than Republican governor Tommy Thompson who is known as a very ambitious reformer of welfare (e.g. Wiseman (1996), p. 532). And in New Jersey, Democratic assembly majority leader Wayne R. Bryant - and not the governor - was the main mover of welfare reform (e.g. Haskins (2006), p. 34). Both in Wisconsin and in New Jersey government was divided at that time. I also empirically explore several other potential explanations of my finding, but none of them is consistent with the data. It indeed seems to be competition between governor, senate, and house that makes divided government reform more. Finally, the passage of the US Welfare Reform at the federal level in 1996 is itself an illustrative example: The Republicans used their majority in both chambers of Congress to challenge Democratic President Clinton in the realms of welfare reform by passing significant reform bills. The Clinton administration reacted using vetoes and counter-proposals. In the end, the largest welfare reform since the New Deal was adopted under divided government.

The following section presents the related literature. Section 3 gives some background on US welfare politics and presents the data. Section 4 covers the estimation strategy and results. Section 5 explores potential explanations of the counter-intuitive finding. Section 6 concludes.

\section{Related Literature}

My work relates to the growing strand of literature on causes and consequences of divided government. Classics on the causes include, for example, Alesina and Rosenthal (1995), Alesina and Rosenthal (1996), and Alesina and Rosenthal (2000) who put forward a balancing theory of divided government, i.e. voters split political power between political actors of different partisanship to get an ideologically intermediate policy in the end. ${ }^{1}$ Another classic is Chari et al. (1997) arguing that divided government may be a result of voters wanting a Republican who is good at keeping overall taxes down as president, but a Democrat who is good at bringing pork home as constituency representative in Congress. ${ }^{2}$ More recent work stresses the control element of divided government: While Fox and Weelden (2010) present more effective overseight as a theoretical argument in favor of having a divided government, Schelker (2012) shows that voters - to restrict power of the unaccountable - are indeed $10 \%$ more likely to elect a divided government into office when the incumbent governor cannot be reelected.

The literature on consequences of divided government has so far mainly focused on fiscal policy and budgets. Roubini and Sachs (1989) is an early paper showing for OECD countries that during crises coalition and minority governments in general are bad at managing the budget. For US states in particular, Poterba (1994) and Alt and Lowry (1994) show that unified governments are better able to respond to fiscal crises. More recent work stresses how budgets tend to be late under divided governments, see Klarner et al. (2012) and Andersen et al. (2012). The latter paper, for example, finds that the budget is 10 to $20 \%$ more likely to be late under divided government and offers a theoretical explanation based on a war of attrition between the parties (Alesina and Drazen (1991)).

\footnotetext{
${ }^{1}$ See Fiorina (1996) for a similar argument and an overview of more classical arguments.

${ }^{2}$ See Jacobson (1990) for a related argument.
} 
In contrast, the present paper is concerned with the effect of divided government on the adoption of economic reforms. Most theoretical work has focused on reform deadlock as a natural consequence of divided government. Classics on this are Sundquist (1988) and Cutler (1988). More recent examples include Howitt and Wintrobe (1995), Tsebelis (1995), and Tsebelis (2002). The former make the theoretical argument that under stiff political competition such as under divided government no party may dare to bring up a political issue since it is afraid that the opposing second party may be strong enough to implement a policy that is even worse than the status quo from the perspective of the first party. The potential result is reform inaction. Similarly, the work by Tsebelis shows that the likelihood of reforms drops in the number of relevant political veto players and the partisan diversity among them. Again, reform deadlock is the predicted consequence of divided government.

On the empirical side, however, evidence is scarce. There is a literature on policy innovation in political science started by Walker (1969) and reviewed in Berry and Berry (2007). ${ }^{3}$ Important examples analyzing the effects of divided government on legislative accomplishment at the US federal level are Mayhew (2005) and Binder (1999). The latter is extended in Binder (2003). While Mayhew shows that the number of passed laws that are relevant according to expert judgment does not differ between divided and unified governments, Binder argues that one has to take the overall political agenda into account. She measures legislative accomplishment as the share of bills passed out of all bills discussed in newspaper editorials and finds that divided governments gridlock on a larger share of the agenda. Shipan (2006) has however shown that the latter approach has the problem that the political agenda tends to be larger under divided governments and is thus endogenous. A recent overview of this inconclusive literature is provided in Binder (2011). Results depend to a large degree on the definition of legislative productivity and the focus is almost exclusively on the US federal level giving not more than 30 observations for the analysis. ${ }^{4}$ In contrast, this paper investigates the US state level allowing for considerably deeper econometric analysis and looks at de facto implemented economic reforms in the well-defined policy area of welfare reform.

So far, there is no literature in economics analyzing the effect of divided government on the adoption of particular economic reforms. Bjørnskov and Potrafke (2013) analyze how party ideology in US states affects an economic freedom index containing, for example, tax revenue as share of GDP and union density. Although the authors interact their party ideology measures with different forms of government, the main interest lies in the effect of ideology in this paper. Castanheira et al. (2012) look at tax reforms in particular, but investigate a cross-section of European countries with different political systems. They find that countries with more parties in government are more likely to reform their tax system.

The paper also contributes to the literature on the US Welfare Reform. There is a large policy evaluation literature on this issue. For reviews, see Harvey et al. (2000) or Blank (2002). Most of this literature does, however, not take into account the political economy aspect of

\footnotetext{
${ }^{3}$ Berry and Berry (1990) and Berry and Berry (1992) are important examples using event history analysis that both touch the topic of divided government.

${ }^{4}$ Bowling and Ferguson (2001) and Rogers (2005) are exceptions looking at the state level. But the former conducts a cross-sectional analysis of the 1994 legislative sessions only and the latter a cross-sectional analysis of 23 states only. Besides being unable to run within-state analyses, both papers do not take potential endogeneity of divided government into account.
} 
the reform: Since it is not random which states reform their welfare system, the evaluation literature may be faced with problems of endogeneity. To better understand which states reform and why can therefore also help to better understand the effect of different welfare policies. There is almost no work on the political economy of the US Welfare Reform. Some examples focusing mostly on welfare caseload, racial issues, and interactions between federal and state level as explanatory factors are Lieberman and Shaw (2000), Soss et al. (2001), Fellowes and Rowe (2004), and Soss et al. (2008). Bernecker and Gathmann (2013) look at the relevance of reputational concerns of US governors in shaping the US Welfare Reform. None of these papers investigates the effect of divided government.

In broader terms, this paper is part of the literature in economics analyzing the political economy of reforms. Most of this literature is theoretical. Famous examples are Fernandez and Rodrik (1991), Dewatripont and Roland (1995), or Cukierman and Tommasi (1998). In terms of methods, the paper is closest to the political economy literature analyzing policy choices in US states (often using panel data regressions). Important examples include Besley and Case (1995), List and Sturm (2006), and Besley et al. (2010). For an overview, see Besley and Case (2003). None of these looks at divided government or welfare reforms in particular.

\section{Background and Data}

\subsection{US Welfare Politics}

Before the landmark US Welfare Reform under President Clinton in 1996, the "Aid to Families with Dependent Children (AFDC)" program had been in place for several decades. As an entitlement program, it provided financial assistance to eligible families and almost all of its rules were determined at the federal level. Since 1962, states had the possibility to apply for welfare waivers at the Department of Health and Human Services at the federal level under Section 1115 of the Social Security Act. If approved, states could deviate from the rules set at the federal level and experiment with own policy rules as suggested in the waiver application. Such waivers became common in the 1980s when welfare caseloads began to rise and many states wanted to restrict welfare (Lieberman and Shaw (2000)). The common spirit of many such waivers was to go "from welfare to workfare". Major policy changes implemented include work requirements, family caps, time limits, and sanctions. See Harvey et al. (2000) for more details on these waivers.

In 1996, President Clinton signed the "Personal Responsibility and Work Opportunity Act" which abolished the "Aid to Families with Dependent Children (AFDC)" in favor of the new "Temporary Assistance for Needy Families (TANF)" program with new federal rules. Within these federal guidlines, the reform also granted states more liberty to decide on their own welfare policy rules and in fact decentralized welfare to the state level. Now, states no longer have to apply at the federal level when they want to reform the welfare system. The 1996 federal level reform also further strengthened states' financial incentives to reform welfare by switching from matching to block grants. Policy changes in the areas of work requirements, family caps, time limits, and sanctions have remained popular at the state level until today.

The 1996 US Welfare Reform is usually considered the most important one since the New 
Deal. Still, the political economy of it seems heavily underresearched. We know almost nothing about which states decided to reform their welfare systems and why. Welfare reform case studies and anecdotal evidence suggest that the governors and their electoral concerns play a very important role. This is analyzed in detail in Bernecker and Gathmann (2013). But since no welfare legislation can be passed without the consent of state senate and state house, the state legislatures clearly also have their parts. Both, governors and state legislators have been identified as "key actors" in the process of welfare reform (Liebschutz (2000), p. 18).

In many states, reforming governors intensively collaborated or struggled with their state legislatures. Liebschutz (2000), for instance, gives examples from Florida, Mississippi, New York, Washington, and Wisconsin (pp. 19, 60, 109). In several of these instances government was divided. There is also evidence that in some states it was the state legislatures even taking the initiative in the welfare reform process, for example in Wisconsin in 1979 (before well-known reformer Tommy Thomspon took the gubernatorial office) or in New Jersey. In both cases Democratic legislators took the lead (Haskins (2006), pp. 34-35). Thus, it seems worthwhile to also look at the interplay between governors and state legislatures in the process of welfare reform. This makes the setting an interesting case for studying the effects of divided government on reform-making.

Another interesting feature of welfare politics is that it is typically a very partisan topic in the US (e.g. Weissert (2000), p. 5, or Royed and Borrelli (1997), p. 543). Thus, if it was true that differing partisan positions indeed lead to gridlock under divided government, one should definitely observe this for the area of welfare politics.

\subsection{Data}

Welfare Reform. This analysis is based on a novel data set on welfare policy reform activity in US states from 1978 to 2010 that has been assembled and coded from several sources. The main dependent variable in the econometric analysis is a dummy that is equal to one if a state has conducted a welfare reform in a given year. Before the 1996 Welfare Reform at the federal level, the reform dummy is equal to one if a state has filed a welfare waiver application. The data on waivers have been obtained and cross-checked from Lieberman and Shaw (2000), Koerper (1996), and Crouse (1999). Although the dummy captures waiver applications this reflects de facto welfare policy changes since only a tiny fraction of these applications have been rejected by the federal level or withdrawn by the state level. ${ }^{5}$ Since the 1996 Welfare Reform at the federal level, states have not submitted waivers anymore and the reform dummy is equal to one if a state has changed its welfare policy. Data on the post 1996 welfare policy changes are obtained from the Urban Institute that keeps track of all changes and maintains a large Welfare Rules Database (Urban Institute (2012)).

The baseline welfare reform dummy captures policy changes in the relevant areas of family

\footnotetext{
${ }^{5}$ For example, the rejection rate in Clinton's first term was 3\%. Between 1978 and 1996, i.e. during the whole waiver period under consideration here, less than $8 \%$ of all waivers have ever been withdrawn, possibly by subsequent governments. For details on these numbers, see Lieberman and Shaw (2000). The approach of using application dates to measure reform is preferable over using actual implementation dates since the application date is when the political decision at the state level has been made and the implementation dates are often delayed due to interference of the Department of Health and Human Services at the federal level.
} 
caps, work requirements, sanctions, and time limits. A family cap rules that if a single mother on welfare conceives an additional child she does not receive additional welfare benfits for it. Work requirement rules state how many hours a welfare recipient has to work to be eligible for benefits, what the exemptions are for being ill etc. Sanctions define what happens when recipients do not comply with the rules of the system. These sanctions differ, for example, in duration and severity. Time limits state, for example, for how many years in their entire lifetime recipients are eligibile to receive benefits. For details on these rules and the coding, see the Data Appendix, in particular Appendix Table 18. In total, the baseline reform dummy is based on changes in 14 relevant policy rules and is equal to one if a change of at least one of them occured in a particular state and year. The dummy mean over all state year observations in the sample is 0.23 , i.e. in any given year about one quarter of all states reform at least some part of their welfare system. Most reforms restrict access to welfare. The ratio of contractive versus expansive reforms is more than three to one.

For robustness checks, alternative welfare reform dummies and count variables are constructed and used in the analysis. A narrow reform measure is based on a subset of only 8 highly relevant rules and only takes into account large changes in these rules. A broad reform measure is based on an extended set of 24 policy rules and also reflects changes in those rules. An example for such a rule in the extended set is that you need to get your children vaccinated to be eligible for welfare benefits. For details regarding data sources and coding of the welfare policy rules, see the Data Appendix. Section 4 gets back to the different reform measures.

The resulting data set spans the years from 1978 to 2010 and gives a comprehensive overview of welfare reform activity in US states. The distribution of welfare reforms over time is depicted in Figure 1. One can see that welfare reforms were especially popular in the early 1990s. Up to more than $40 \%$ of states per year filed waiver applications in these years. This was the period when caseloads were high which in many cases led to the political wish to restrict access to welfare by shifting the focus of the system "from welfare to workfare". This was also the time when President Clinton announced to "end welfare as we know it". In 1996, the Welfare Reform under Clinton decentralized considerable power to shape welfare to the state level. And one can clearly see from Figure 1 that many states used the newly gained liberty to do so: The years from 1997 to 2000 are those in the sample with the highest number of states per year conducting welfare reforms (up to 80\%). Since 2001, the share of reforming states per year has usually fluctuated around $20 \%$. Thus, states have remained active in shaping their welfare policy rules until today.

Divided Government. The main explanatory variable is a dummy that is equal to one if a state has a divided government in a given year. Divided government means that in at least one of the legislative chambers the majority is from a different party than the govenor. Thus, this includes so called split branch governments where the governor is confronted with majorities from the opposing party in both chambers of the legislature as well as split legislature governments where the two legislative chambers have majorities from different parties. ${ }^{6}$ For an

\footnotetext{
${ }^{6}$ Nebraska has a unicameral legislature and is excluded from the econometric analysis (like Alaska and Hawaii). This is standard in the literature, see for example Lott and Kenny (1999). The analysis also excludes governments with an independent governor or split chambers (where both Democrats and Republicans have the same amount of seats).
} 
Figure 1: Incidence of Reforms over Time

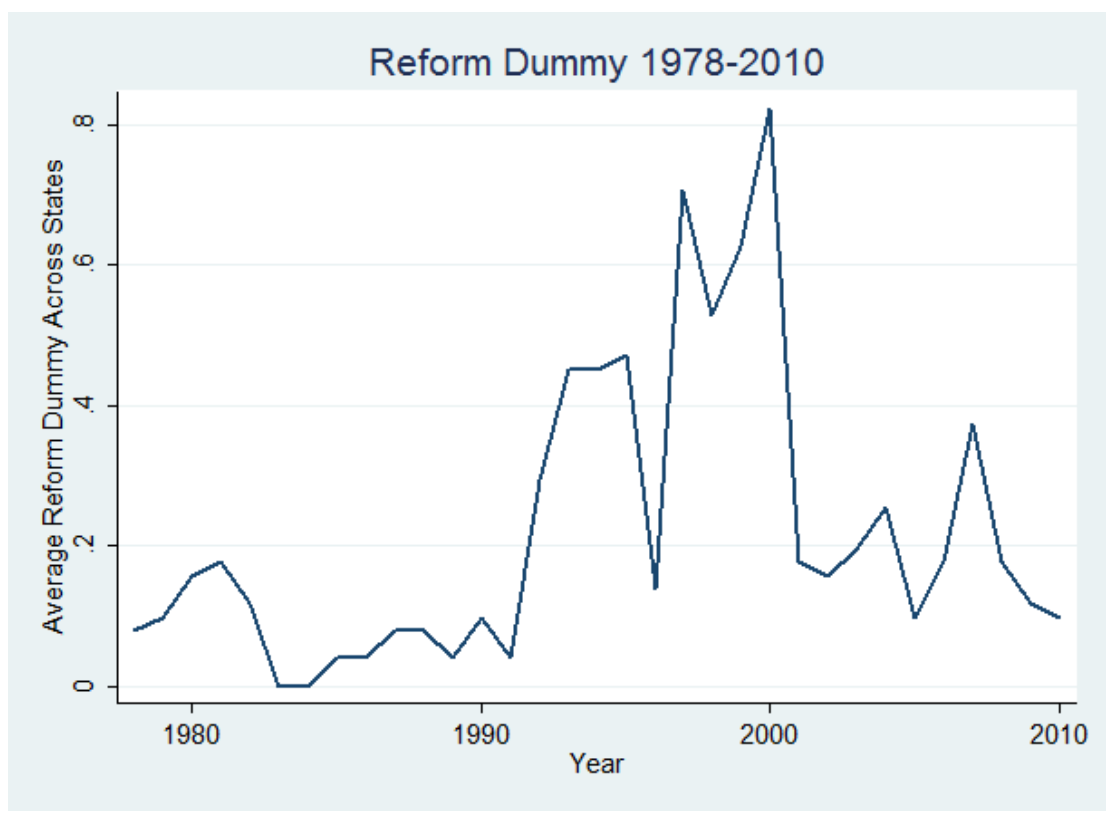

illustration of the different types of divided government, see Figure 2. Section 5 gets back to the different types. The data on party control of state governments and legislatures have been obtained from Klarner (2003). From 1978 to 2010, more than one half of all state governments were divided. Out of these, about $60 \%$ were split brach and $40 \%$ split legislature governments.

Figure 2: Different Forms of State Government. G means Governor, S means Senate, H means House. The colors black and grey symbolize two different parties. Colored letters reflect party dominance of that institution by the respective party.

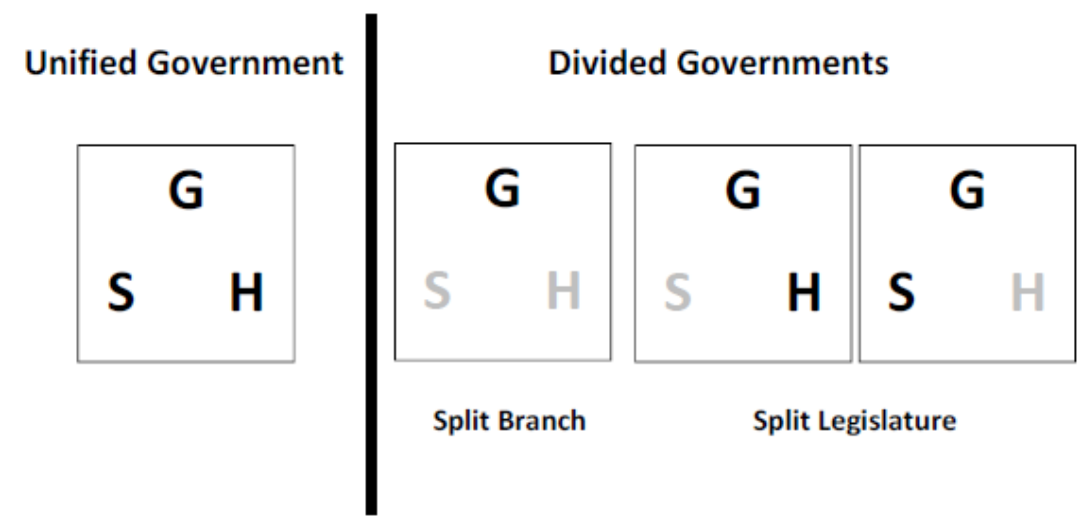

Figure 3 shows the cross-sectional distribution of welfare reforms and divided governments across US states. The grey bars indicate the share of years between 1978 and 2010 in which a state had a divided government. Among the states which had a divided government very often are, for example, New York and Delaware. At the opposite end, with the state government being unified almost all of the time, one finds states such as Georgia or South Dakota. Note that not a single state in the sample had either unified or divided governments for the whole time span under consideration. The black bars show the share of years between 1978 and 2010 in which a state has reformed its welfare system. These bars are on average considerably shorter 
than the divided government bars. Note, however, that also in terms of welfare reform years there is quite substantial variation between states. Wisonsin, for example, gets close to $40 \%$ whereas Idaho barely reaches $10 \%$. For maps showing the distribution of reforms and divided government across states, see the Appendix.

Figure 3: Share of Years with Reform and Divided Government

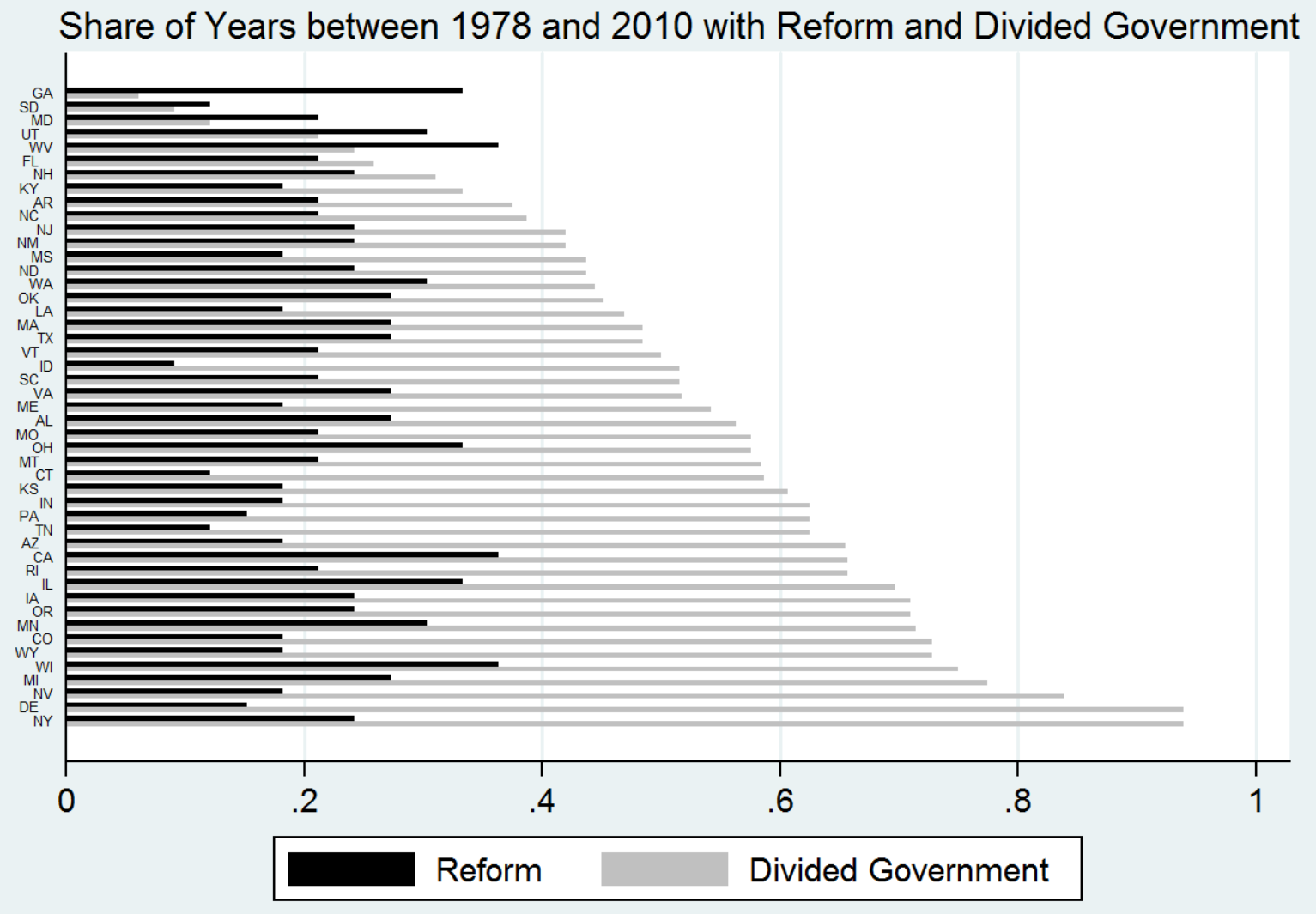

Controls. In the econometric analysis, I control for a wide range of additional variables. Descriptive statistics of all variables are provided in Table 1. Means conditioned on the type of government (divided or unified) are presented in Appendix Table 15. The demographic variables include per capita income, population size, black and latino population, population older than 65 and younger than 18. These controls are standard in US state level policy analyses. For potential relevance for welfare, I add the share of AFDC/TANF recipients (welfare caseload), the percentage of unemployed and immigrants, the deflated total state revenue per capita, unmarried birth, the maximum AFDC/TANF benefit for a family of three, and the 90th/10th ratio of household income. Most of the demographic data are taken from the Statistical Abstract (United States Census Bureau (2011)). As political controls, I add information related to the governor (the party, if he/she can be reelected, an election year dummy), information related to the state legislature (the Demcratic seat shares in both legislative chambers, the percentage of women in the state legislature, the polarization of both chambers), information about divided government at the federal level, and ideology measures (the percentage of Democratic votes in the last presidential election and ideology measures for the state government and the state 
citizens taken from Berry et al. (1998)). The data have been obtained from different sources. For data sources and variables explanations, see the Data Appendix.

Table 1: Summary Statistics

\begin{tabular}{|c|c|c|c|}
\hline Variable & $\mathbf{N}$ & Mean & Std. Dev. \\
\hline Reform Dummy & 1551 & 0.2302 & 0.4211 \\
\hline Broad Reform Dummy & 1551 & 0.2585 & 0.4380 \\
\hline Broad Reform Count Variable & 1551 & 0.5796 & 1.4906 \\
\hline Narrow Reform Dummy & 1551 & 0.1792 & 0.3837 \\
\hline Narrow Reform Count Variable & 1551 & 0.2469 & 0.6214 \\
\hline Reform Package (including contractive and expansive policies) & 705 & 0.0766 & 0.2661 \\
\hline Reform Dummy Geographic Neighbors & 1551 & 0.2241 & 0.2748 \\
\hline Reform Dummy Population Size Neighbors & 1551 & 0.2253 & 0.2713 \\
\hline Divided Government Dummy & 1474 & 0.5285 & 0.4994 \\
\hline Split Legislature Dummy & 1474 & 0.1900 & 0.3924 \\
\hline Split Branch Dummy & 1474 & 0.3385 & 0.4734 \\
\hline Divided Government with past Divided Government & 698 & 0.3983 & 0.4899 \\
\hline Divided Government with past Unified Government & 698 & 0.1117 & 0.3153 \\
\hline Divided Government with past Dem. Unif. Govt. & 698 & 0.0802 & 0.2718 \\
\hline Divided Government with past Rep. Unif. Govt. & 698 & 0.0315 & 0.1748 \\
\hline Divided Govternment via General Elections & 698 & 0.0802 & 0.2718 \\
\hline Divided Government via Midterm Elections & 698 & 0.0315 & 0.1748 \\
\hline Share of AFDC/TANF Recipients in Pop. (Caseload) & 1551 & 0.0298 & 0.0175 \\
\hline$\%$ Unemployed $(/ 1000)$ & 1551 & 0.0060 & 0.0021 \\
\hline Deflated Total State Revenue per Capita (/1000) & 1551 & 2.1730 & 0.6871 \\
\hline Unmarried Birth (per 1,000 unmarried women) & 1493 & 28.863 & 9.3541 \\
\hline Maximum AFDC/TANF Benefit Level for a Family of $3(/ 1000)$ & 1551 & 0.3642 & 0.1373 \\
\hline Per Capita Income $(/ 1000)$ & 1551 & 22.688 & 10.299 \\
\hline Population $(/ 1000000)$ & 1551 & 5.5337 & 5.8385 \\
\hline$\%$ Population Black & 1551 & 10.189 & 9.4377 \\
\hline$\%$ Population Latino & 1457 & 6.7483 & 8.5792 \\
\hline$\%$ Population 65 or older & 1551 & 12.430 & 1.8055 \\
\hline$\%$ Population 17 or younger & 1551 & 26.127 & 2.6259 \\
\hline$\%$ Immigrant Population & 1551 & 1.8831 & 1.9715 \\
\hline 90th/10th Ratio of Household Income & 1551 & 7.9765 & 1.3750 \\
\hline Governor Lame Duck (i.e. cannot be reelected) & 1551 & 0.2650 & 0.4415 \\
\hline Gubernatorial Election & 1551 & 0.2785 & 0.4484 \\
\hline Polarization Senate & 1551 & 0.3488 & 0.1138 \\
\hline Polarization House & 1551 & 0.3548 & 0.1086 \\
\hline$\%$ Women in State Legislature & 1551 & 18.437 & 8.4792 \\
\hline \% Democratic Votes in Last Presidential Election $(/ 1000)$ & 1551 & 0.0446 & 0.0079 \\
\hline Citizens Ideology (Berry et al. 1998) (/1000) & 1551 & 0.0489 & 0.0154 \\
\hline Democratic Seat Share in Senate & 1551 & 0.5607 & 0.1793 \\
\hline Democratic Seat Share in House & 1551 & 0.5587 & 0.1716 \\
\hline Government Ideology (Berry et al. 1998) (/1000) & 1457 & 0.0500 & 0.0242 \\
\hline Governor Party Dummy $(1=$ Democrat $)$ & 1551 & 0.5199 & 0.4962 \\
\hline Divided Government at Federal Level & 1551 & 0.6061 & 0.4888 \\
\hline
\end{tabular}

Notes: For details on coding, variables meanings, and data sources, see the Data Appendix. The variables "Divided Government with past Dem. Unif. Govt." and "Divided Government via General Elections" are not the same, they are highly correlated, but differ for several observations. Mean and standard deviation happen to be the same. The same is true for the variables pair "Divided Government with past Rep. Unif. Govt." and "Divided Government via Midterm Elections". See the Data Appendix for details.

\section{Empirical Strategy and Results}

\subsection{Empirical Strategy}

Panel data regressions build the main part of the analysis. The dependent variable is the welfare reform dummy. The treatment of interest is divided versus unified government which differs 
across states and time.

The baseline estimation equation is:

$$
R_{s t}=\alpha_{t}+\gamma_{0 s}+\gamma_{1 s} * t+\delta * D_{s t}+X_{s t} * \beta+\epsilon_{s t}
$$

$R_{s t}$ is a dummy that is equal to one if state $s$ has conducted a welfare reform in year $t . D_{s t}$ is a dummy that is equal to one if state $s$ had a divided government in year $t$. $\delta$ thus captures the treatment effect of interest. $\alpha_{t}$ captures year fixed effects, $\gamma_{0 s}$ and $\gamma_{1 s}$ capture state fixed effects and allow for state specific linear trends. $X_{s t}$ are relevant controls. Standard errors are clustered at the state level to take serial correlation into account (Bertrand et al. (2004)).

For simplicity, linear probability models are estimated almost throughout the paper. Linear probability models do not take into account the binary character of the outcome variable. However, estimation of fixed effects logit models yields even slightly stronger results. See Appendix Table 11. Also on all other instances where a standard linear probability model does not seem fully adequate, alternative specifications using other estimation techniques such as Arellano-Bond or Poisson regressions are always reported in the Appendix.

Besides standard demographic controls, $X_{s t}$ includes different variables related to welfare to take potential endogeneity issues into account. One problem with identification could, for example, be that welfare state crisis is an omitted variable that may cause both divided government and welfare reform. This is why the share of welfare recipients in the population, the share of unemployed, state revenue, and other controls are included as measures of welfare state crisis. It is also known that immigration and race issues frequently come up in debates about the welfare state (Schram et al. (2003)). The analysis therefore also controls for the racial composition and immigrants in the population. For the field of welfare policy, all these socioeconomic controls can also be considered being proxies for the demand of welfare reform legislation.

Even controlling for a wide range of socioeconomic variables, several econometric concerns may remain. This is what the subsections following the main results deal with: Further potentially omitted variables such as political or ideological factors are included in the analysis. A state's reform history and reform spillovers across states are taken into account. Another subsection deals with the measurement of welfare reform by checking alternative dummy and count dependent variables based on broader or narrower welfare policy rules sets. Potential reverse causality and other endogeneity issues are not of any concern as shown by a close elections analysis providing quasi-random variation in the type of government. For analyses regarding differential effects for different subsamples, e.g. differences depending on government history, on being a Southern state or not, or on looking before or after the federal level reform in 1996, see the Appendix.

\subsection{Effect of Divided Government on Reform Adoption}

Main Result. Table 2 presents the main results. The dependent variable is the reform dummy that indicicates if a state has conducted a welfare reform in a given year or not. The main explanatory variable is the divided government dummy. Specification (1) includes year fixed 
effects, specification (2) adds state fixed effects, specification (3) adds state specific linear time trends. In all three specifications, the effect of divided government on reform is highly significant and in the range of 4 to 6 percentage points. This means that the likelihood of observing a welfare reform is 4 to 6 percentage points higher under divided government than under unified government. Given the fact that between 1978 and 2010 the average unconditional probability of a US state to conduct a welfare reform is $23 \%$, the effect of divided government on the probability to adopt a welfare reform amounts to more than $25 \%$ of the unconditional probability to implement a reform according to baseline specification (3). All following specifications include year fixed effects, state fixed effects, and state specific linear time trends.

Table 2: Divided Government and Reform

\begin{tabular}{|c|c|c|c|c|c|c|c|}
\hline & (1) & $(2)$ & (3) & (4) & (5) & (6) & (7) \\
\hline Divided Government & $\begin{array}{r}0.0413^{* *} \\
(0.0195)\end{array}$ & $\begin{array}{c}0.0552^{* * *} \\
(0.0183)\end{array}$ & $\begin{array}{c}0.0600^{* * *} \\
(0.0204)\end{array}$ & $\begin{array}{c}0.0598^{* * *} \\
(0.0203)\end{array}$ & $\begin{array}{c}0.0600^{* * *} \\
(0.0205)\end{array}$ & $\begin{array}{c}0.0602^{* * *} \\
(0.0201)\end{array}$ & $\begin{array}{c}0.0649^{* * *} \\
(0.0229)\end{array}$ \\
\hline Share of AFDC/TANF Recipients (Caseload) & & & & $\begin{array}{c}0.523 \\
(2.453)\end{array}$ & & & $\begin{array}{l}-0.201 \\
(2.481)\end{array}$ \\
\hline \% Unemployed $(/ 1000)$ & & & & & $\begin{array}{l}-0.546 \\
(10.58)\end{array}$ & & $\begin{array}{l}-17.29 \\
(15.58)\end{array}$ \\
\hline Deflated State Revenue per cap. (/1000) & & & & & & $\begin{array}{l}-0.0103 \\
(0.0513)\end{array}$ & $\begin{array}{l}-0.00329 \\
(0.0555)\end{array}$ \\
\hline Unmarried Birth (per 1000 unmarried women) & & & & & & & $\begin{array}{c}0.0126 \\
(0.00925)\end{array}$ \\
\hline Max. AFDC/TANF Benefit Family of 3 (/1000) & & & & & & & $\begin{array}{l}0.273 \\
(0.629)\end{array}$ \\
\hline Per Capita Income (/1000) & & & & & & & $\begin{array}{l}-0.0176 \\
(0.0175)\end{array}$ \\
\hline Population (/1000000) & & & & & & & $\begin{array}{c}0.0579 \\
(0.0714)\end{array}$ \\
\hline \% Population Black & & & & & & & $\begin{array}{l}-0.0237 \\
(0.0452)\end{array}$ \\
\hline$\%$ Population Latino & & & & & & & $\begin{array}{l}-0.0260 \\
(0.0265)\end{array}$ \\
\hline$\%$ Population 65 or older & & & & & & & $\begin{array}{l}-0.0459 \\
(0.0657)\end{array}$ \\
\hline$\%$ Population 17 or younger & & & & & & & $\begin{array}{c}0.0282 \\
(0.0174)\end{array}$ \\
\hline \% Immigrant Population & & & & & & & $\begin{array}{l}-0.00699 \\
(0.00787)\end{array}$ \\
\hline 90th/10th Ratio of Household Income & & & & & & & $\begin{array}{l}0.00941 \\
(0.0142)\end{array}$ \\
\hline Year FE & YES & YES & YES & YES & YES & YES & YES \\
\hline State FE & NO & YES & YES & YES & YES & YES & YES \\
\hline State Specific Linear Trend & NO & NO & YES & YES & YES & YES & YES \\
\hline Observations & 1,474 & 1,474 & 1,474 & 1,474 & 1,474 & 1,474 & 1,343 \\
\hline R-squared & 0.253 & 0.283 & 0.315 & 0.315 & 0.315 & 0.315 & 0.326 \\
\hline
\end{tabular}

Welfare State Crisis. It may be that welfare state crises are common causes of both divided government and welfare reform. Specifications (4), (5), and (6) therefore control for the share of welfare recipients, the share of unemployed in the population, and for state revenue. State revenue can be considered as a measure of fiscal crisis, results are the same when using state expenditures or state debt instead (not reported). Neither of these controls is significant, but the effect of divided government keeps its size and significance. This is also the case when adding the full range of demographic controls in specification (7). These controls include the share of immigrants, the 90th/10th percentile ratio of household income (as inequality 
measure), the incidence of unmarried birth (since AFDC/TANF policies sometimes aimed to reduce unmarried birth), the maximum welfare benefit for a family of three, the per capita income, the population size, the share of black or latino people, the share of people older than 64, and the share of people younger than 18. All the controls are lagged by one year since politics may need some time to react. None of the controls is significant. The effect of divided government, on the other hand, is still significant and is 6.5 percentage points large. Results are the same when taking the current values of the demographic variables or changes in the demographic variables compared to the previous year as controls (not reported).

\subsection{Potential Other Reform Drivers}

Political Factors. This subsection explores political and ideological factors and reform spillovers across states as other potentially relevant drivers of welfare reform. Table 3 checks the inclusion of other prominent political factors besides divided government. Specification (1) controls for lame duck governors, i.e. governors who cannot be reelected and may have different incentives. The control is not significant. Specifications (2) and (3) check if the results are affected by upcoming or just passed elections. It seems that in the year just after a gubernatoral election the reform adoption propensity is lower. Preparation of welfare reform may just take some time. The important thing to note here is that none of the gubernatorial controls affects the divided government finding. Specifications (4) and (5) include controls related to the state legislature. Specification (4) checks the effect of polarization of chambers measured as 0.5-|democratic seat share-0.5|, ranging from 0 for a fully Democratic or Republican chamber to up to 0.5 for a seat share of exactly 0.5 for each party. The significant coefficient for the polarization of the House is to be interpreted as follows: A 10 percentage points decrease in the absolute distance of the Democratic seat share from 50\% (implying increasing polarization of the chamber) increases the likelihood of observing a welfare reform by 5.36 percentage points. Thus, more polarized Houses seem to be more likely to reform. In terms of interpretation, this finding fits the divided government finding. However, even when controlling for polarization, the effect of the divided government dummy itself also stays significant and keeps its size. Specification (5) controls for the share of women in the state legislature. It shows that having more women seems to reduce the likelihood of a welfare reform being adopted. This is in line with standard results in the literature. ${ }^{7}$ The effect of divided government is not affected. The same is true for specification (6) which includes a dummy that is one for all years in which the federal government was divided. Specification (7) finally includes all political controls from before simultaneously. Again, the effect of divided government is stable and significant. Thus, even when taking into account several other political key variables, divided governments are significantly and relevantly more likely to reform the welfare system than unified governments.

Ideological Factors. A very relevant political factor in shaping welfare reform may be ideology of the state population, the state legislature, or the state governor. Table 4 therefore

\footnotetext{
${ }^{7}$ Since adopting a welfare reform typically restricts access to welfare in this data, this finding is consistent, for example, with Lott and Kenny (1999) who find that in the US extending suffrage to women came along with increases in government spending and more liberal voting by representatives, Chattopadhyay and Duflo (2004) who show that women in India implement different public good provision policies compared to men, or Funk and Gathmann (2014) revealing that women in Switzerland have stronger preferences for welfare compared to men.
} 
Table 3: Divided Government, other Political Factors and Reform

\begin{tabular}{|c|c|c|c|c|c|c|c|}
\hline & (1) & $(2)$ & (3) & $(4)$ & (5) & $(6)$ & $(7)$ \\
\hline Divided Government & $\begin{array}{c}0.0650^{* * * *} \\
(0.0228)\end{array}$ & $\begin{array}{c}0.0650^{* * *} \\
(0.0231)\end{array}$ & $\begin{array}{c}0.0636^{* * * *} \\
(0.0228)\end{array}$ & $\begin{array}{c}0.0597^{* *} \\
(0.0241)\end{array}$ & $\begin{array}{c}0.0705^{* * *} * \\
(0.0221)\end{array}$ & $\begin{array}{c}0.0649^{* * * *} \\
(0.0229)\end{array}$ & $\begin{array}{c}0.0637^{* * * *} \\
(0.0234)\end{array}$ \\
\hline Governor Lame Duck & $\begin{array}{c}-0.00217 \\
(0.0279)\end{array}$ & & & & & & $\begin{array}{c}0.00261 \\
(0.0285)\end{array}$ \\
\hline Year before Gubernatorial Election & & $\begin{array}{c}-0.00309 \\
(0.0302)\end{array}$ & & & & & $\begin{array}{l}-0.0187 \\
(0.0321)\end{array}$ \\
\hline Year after Gubernatorial Election & & & $\begin{array}{c}-0.0602^{* *} \\
(0.0262)\end{array}$ & & & & $\begin{array}{c}-0.0630^{* *} \\
(0.0295)\end{array}$ \\
\hline Polarization Senate & & & & $\begin{array}{l}-0.145 \\
(0.282)\end{array}$ & & & $\begin{array}{l}-0.104 \\
(0.283)\end{array}$ \\
\hline Polarization House & & & & $\begin{array}{c}0.536^{* *} \\
(0.251)\end{array}$ & & & $\begin{array}{c}0.502^{*} \\
(0.260)\end{array}$ \\
\hline$\%$ Women in State Legislature & & & & & $\begin{array}{c}-0.0142^{* * *} \\
(0.00510)\end{array}$ & & $\begin{array}{r}-0.0138^{* *} \\
(0.00533)\end{array}$ \\
\hline Divided Government at Federal Level & & & & & & $\begin{array}{l}0.0377 \\
(0.131)\end{array}$ & $\begin{array}{l}0.0231 \\
(0.129)\end{array}$ \\
\hline Demographic Controls (lagged one year) & YES & YES & YES & YES & YES & YES & YES \\
\hline Year FE & YES & YES & YES & YES & YES & YES & YES \\
\hline State FE & YES & YES & YES & YES & YES & YES & YES \\
\hline State Specific Linear Trend & YES & YES & YES & YES & YES & YES & YES \\
\hline Observations & 1,343 & 1,343 & 1,343 & 1,343 & 1,343 & 1,343 & 1,343 \\
\hline R-squared & 0.326 & 0.326 & 0.328 & 0.328 & 0.331 & 0.326 & 0.335 \\
\hline
\end{tabular}

introduces several ideological controls into the analysis. Specifications (1) and (2) add the share of Democratic votes in the last presidential election and the citizen ideology measure by Berry et al. (1998). The latter measure is constructed from the ideology of state congressional delegations. See the Data Appendix for details. Neither of the two variables affects reforming or the divided government finding. Specifications (3) and (4) investigate potential effects from the partisan composition of the state legislatures. While (3) introduces the Democratic seat shares in the two chambers, (4) also interacts these seat shares with a Democratic chamber majority dummy, thus allowing partisan effects to be different depending on majority versus minority status in the chamber. None of these controls is significant, the divided government effect is stable in size and significance. Specification (5) uses the government ideology measure from Berry et al. (1998) as control, specification (6) a simple Democratic governor party dummy. Again, the divided government result is not affected. Specification (7) adds all controls from before simultaneously. This only seems to strengthen the divided government effect. Specification (8), finally, interacts the divided government dummy with the Democratic governor dummy allowing the divided government effect to be different for governors of different partisanship. Still, there do not seem to be any ideological differences. The divided government effect is still significant and reaches about 8 percentage points in size.

Ideology cannot explain welfare reform. Appendix Table 12 reveals that robustness with respect to including ideological controls also holds when restricting attention to contractive welfare reforms only (which cover more than $75 \%$ of all welfare reforms in the data set). Also when being compared to unified Democratic and unified Republican governments separately, divided governments are more likely to reform than both (not reported). The fact that welfare 
reform cannot be explained by a simple story of ideology is also consistent with case studies evidence. For example, in New Jersey it was Democrats enacting a series of welfare reforms in the early 1990s that were even more drastic than Wisconsin's which had been known for strongly stressing workfare over welfare (Haskins (2006), p. 34). Another example is the federal 1996 US Welfare Reform itself which has been signed by Democrat Bill Clinton. Kansas is actually the only state where the Republicans had majorities in both chambers for the whole period of welfare reform (Weissert (2000), p. 9).

Table 4: Divided Government, Ideology and Reform

\begin{tabular}{|c|c|c|c|c|c|c|c|c|}
\hline & (1) & $(2)$ & (3) & (4) & (5) & (6) & (7) & $(8)$ \\
\hline Divided Government & $\begin{array}{c}0.0600^{* * *} \\
(0.0204)\end{array}$ & $\begin{array}{c}0.0600^{* * *} \\
(0.0204)\end{array}$ & $\begin{array}{c}0.0591^{* * *} \\
(0.0207)\end{array}$ & $\begin{array}{c}0.0627^{* * *} \\
(0.0203)\end{array}$ & $\begin{array}{c}0.0608^{* * *} \\
(0.0210)\end{array}$ & $\begin{array}{c}0.0574^{* * *} \\
(0.0189)\end{array}$ & $\begin{array}{c}0.0714^{* * *} \\
(0.0214)\end{array}$ & $\begin{array}{l}0.0773^{*} \\
(0.0425)\end{array}$ \\
\hline \% Dem. Votes Last Presidential Election (/1000) & $\begin{array}{l}-0.295 \\
(2.867)\end{array}$ & & & & & & $\begin{array}{c}1.499 \\
(3.373)\end{array}$ & \\
\hline Citizens Ideology (Berry et al. 1998) (/1000) & & $\begin{array}{l}0.0628 \\
(2.010)\end{array}$ & & & & & $\begin{array}{l}1.053 \\
(2.792)\end{array}$ & \\
\hline Dem. Seat Share Senate & & & $\begin{array}{r}-0.0670 \\
(0.188)\end{array}$ & $\begin{array}{l}-0.379 \\
(0.262)\end{array}$ & & & $\begin{array}{l}-0.384 \\
(0.273)\end{array}$ & \\
\hline Dem. Seat Share House & & & $\begin{array}{l}-0.309 \\
(0.258)\end{array}$ & $\begin{array}{r}-0.0293 \\
(0.239)\end{array}$ & & & $\begin{array}{l}0.0253 \\
(0.255)\end{array}$ & \\
\hline Dem. Seat Share Senate ${ }^{*}$ Dem. Maj. Party in Senate & & & & $\begin{array}{c}0.168 \\
(0.104)\end{array}$ & & & $\begin{array}{l}0.203^{*} \\
(0.116)\end{array}$ & \\
\hline Dem. Seat Share House * Dem. Maj. Party in House & & & & $\begin{array}{c}-0.126 \\
(0.0943)\end{array}$ & & & $\begin{array}{l}-0.107 \\
(0.103)\end{array}$ & \\
\hline Government Ideology (Berry et al. 1998) (/1000) & & & & & $\begin{array}{l}-0.743 \\
(0.796)\end{array}$ & & $\begin{array}{l}-1.425 \\
(1.769)\end{array}$ & \\
\hline Governor Democrat $(0=$ Republican $)$ & & & & & & $\begin{array}{l}-0.0101 \\
(0.0235)\end{array}$ & $\begin{array}{c}0.0334 \\
(0.0514)\end{array}$ & $\begin{array}{c}0.0124 \\
(0.0535)\end{array}$ \\
\hline Divided Government $*$ Governor Democrat & & & & & & & & $\begin{array}{l}-0.0371 \\
(0.0716)\end{array}$ \\
\hline Year FE & YES & YES & YES & YES & YES & YES & YES & YES \\
\hline State FE & YES & YES & YES & YES & YES & YES & YES & YES \\
\hline State Specific Linear Trend & YES & YES & YES & YES & YES & YES & YES & YES \\
\hline Observations & 1,474 & 1,474 & 1,474 & 1,474 & 1,383 & 1,474 & 1,383 & 1,474 \\
\hline R-squared & 0.315 & 0.315 & 0.316 & 0.318 & 0.327 & 0.315 & 0.331 & 0.315 \\
\hline
\end{tabular}

Reform History and Spillovers. Another highly important factor potentially determining welfare reform may be learning from the own past or from others, i.e. reform could depend on yesterday's reform or be affected by policy spillovers between states. Table 5 explores this issue. Specifications (1) and (2) add lagged values of the reform dummy as explanatory variables. None of these is significant and the divided government finding is not affected. The same holds true when employing Arellano-Bond estimation. See Appendix Table A3. Specifications (3) and (4) use lagged average levels of reform in geographically neighboring states as explanatory variables. Reforms in neighboring states do not seem to have an effect on a state's reform propensity. The coefficient of divided government is significant and relevant as before. This is in line with anecdotal evidence stressing how states focused on their own specific welfare programs without relying too much on the experience of neighboring states (see e.g. Liebschutz (2000), p. 18). Specifications (5) and (6) explore controlling for the lagged average level of reform in states with a similar population size. There is a positive reform adoption effect of past reforms in states with similar population size. This may suggest that states copy states with similar size when it comes to reforming. Importantly, the effect of divided government is stable in size and significance across all specifications. The same is true when adding the third 
or fourth lag of any of these controls (not reported).

Table 5: Divided Government and Reform History

\begin{tabular}{|c|c|c|c|c|c|c|}
\hline & (1) & $(2)$ & (3) & $(4)$ & $(5)$ & (6) \\
\hline Divided Government & $\begin{array}{c}0.0655^{* * *} \\
(0.0235)\end{array}$ & $\begin{array}{c}0.0653^{* * *} \\
(0.0238)\end{array}$ & $\begin{array}{c}0.0649^{* * *} \\
(0.0230)\end{array}$ & $\begin{array}{c}0.0647^{* * *} \\
(0.0229)\end{array}$ & $\begin{array}{c}0.0656^{* * *} \\
(0.0227)\end{array}$ & $\begin{array}{c}0.0653^{* * *} \\
(0.0224)\end{array}$ \\
\hline Reform Dummy (t-1) & $\begin{array}{c}-0.0420 \\
(0.0333)\end{array}$ & $\begin{array}{c}-0.0438 \\
(0.0347)\end{array}$ & & & & \\
\hline Reform Dummy (t-2) & & $\begin{array}{l}-0.0330 \\
(0.0291)\end{array}$ & & & & \\
\hline Reform Dummy Geographic Neighbors (t-1) & & & $\begin{array}{c}-0.0843 \\
(0.0708)\end{array}$ & $\begin{array}{c}-0.0793 \\
(0.0720)\end{array}$ & & \\
\hline Reform Dummy Geographic Neighbors (t-2) & & & & $\begin{array}{c}0.0803 \\
(0.0667)\end{array}$ & & \\
\hline Reform Dummy Pop. Size Neighbors (t-1) & & & & & $\begin{array}{c}0.114^{*} \\
(0.0659)\end{array}$ & $\begin{array}{c}0.111 \\
(0.0661)\end{array}$ \\
\hline Reform Dummy Pop. Size Neighbors (t-2) & & & & & & $\begin{array}{l}0.161^{* *} \\
(0.0673)\end{array}$ \\
\hline Demographic Controls (lagged one year) & YES & YES & YES & YES & YES & YES \\
\hline Year FE & YES & YES & YES & YES & YES & YES \\
\hline State FE & YES & YES & YES & YES & YES & YES \\
\hline State Specific Linear Trend & YES & YES & YES & YES & YES & YES \\
\hline Observations & 1,343 & 1,343 & 1,343 & 1,343 & 1,343 & 1,343 \\
\hline R-squared & 0.327 & 0.327 & 0.327 & 0.328 & 0.327 & 0.331 \\
\hline $\begin{array}{l}\text { Notes: The dependent variable in all specifications is a } \\
\text { in a given state and year. Reform Dummy Geographi } \\
\text { states. Reform Dummy Population Size Neighbors is } \\
\text { (where all states are grouped into } 10 \text { different bands } \\
\text { either the majority of the state's lower legislative chan } \\
\text { the governor. For details on any of the variables, see } \\
\text { parentheses. } \\
* * * \\
\mathrm{p}<0.01,{ }^{* *} \mathrm{p}<0.05 \text { and }{ }^{*} \mathrm{p}<0.1 \text {. }\end{array}$ & $\begin{array}{l}\text { reform dumm } \\
\text { Neighbors is } \\
\text { equal to the a } \\
\text { f similar popp } \\
\text { lber or the ma } \\
\text { the Data Apl }\end{array}$ & $\begin{array}{l}\text { that is equal } \\
\text { qual to the a } \\
\text { erage of the } \\
\text { lation size). } \\
\text { jority of the st }\end{array}$ & $\begin{array}{l}\text { o one if one } \\
\text { rage of the r } \\
\text { form dummy } \\
\text { vided Goverr } \\
\text { te's upper le }\end{array}$ & $\begin{array}{l}\text { nore welfare } \\
\mathrm{rm} \text { dummy } \\
\mathrm{r} \text { all states } \\
\text { ent is a dun } \\
\text { lative cham }\end{array}$ & $\begin{array}{l}\text { forms have } \\
\text { all geograpl } \\
\text { th a similar } \\
\text { that is equ } \\
\text { is from ano }\end{array}$ & $\begin{array}{l}\text { en introduced } \\
\text { cally adjacent } \\
\text { ppulation size } \\
\text { to one when } \\
\text { er party than } \\
\text { are shown in }\end{array}$ \\
\hline
\end{tabular}

\subsection{Measurement of Reform}

The baseline reform dummy codes policy changes based on 14 highly relevant welfare policy rules. See Appendix Table 18 for details. Nevertheless, one may argue that the reform measure should take into account all policy rule changes. Or one may argue that it should not only measure if there was a reform or not, but that it should also consider the size of the reform (e.g. number of policy rule changes) or the significance of the reform (e.g. important reforms only). This is why this subsection explores the robustness of the finding with respect to the measurement of reform.

Figure 4 presents the development of the baseline reform dummy, of a broad reform dummy, and of a narrow reform dummy from 1996 to 2010. Note that before 1996 all measures are identical since in the waiver period the measurement of reform is unambiguous. Compared to the baseline measure, the broad dummy definition is based on 24 policy rules by considering 10 additional rules on assets exemptions and special eligibility requirements. See Appendix Table 19 for details. In contrast, the narrow reform dummy restricts attention to a subset of highly relevant policy rules and focuses on large changes. Again, see the Data Appendix for details. As one would expect, there are more reforms when broadening the definition and less reforms when narrowing the definition. Also note that there is considerable comovement of the three different variables across time suggesting that the reform measures habe been coded in a 
Figure 4: Different Measures of Reform after 1996

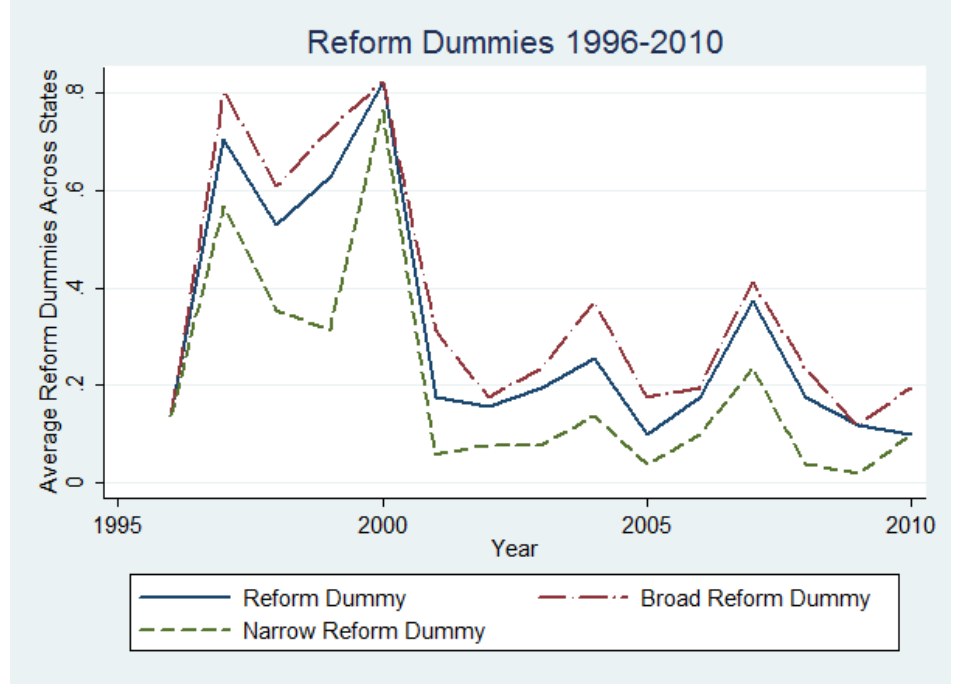

consistent manner.

Table 6 explores using these alternative measures of reform as dependent variables. Specification (1) of the table replicates the baseline estimation from before using the reform dummy. Specification (2) uses the broad definition of welfare reform. The divided government effect is stable. Specification (3) relates to the argument that one should also consider the size of reforms and uses a count variable version of the broad reform dummy from specification (2). Still, the coefficient of divided government is sizable and significant. Specification (4), finally, restricts attention to important reforms only by using the narrow reform measure. Still, the divided government effect is stable in size and significance. Appendix Table 14 shows that the results are robust when employing Poisson estimation. Thus, it is not the case that divided governments pass only minor policy adjustments, while unified governments implement large reforms. In summary, the divided government effect is very robust with respect to the measurement of the dependent variable.

Table 6: Divided Government and Different Measures of Reform

\begin{tabular}{|c|c|c|c|c|}
\hline Dependent Variable: & $\begin{array}{c}(1) \\
\text { Dummy }\end{array}$ & $\begin{array}{c}(2) \\
\text { Broad Dummy }\end{array}$ & $\begin{array}{c}(3) \\
\text { Broad Count Var. }\end{array}$ & $\begin{array}{l}(4) \\
\text { Narrow Count Var. }\end{array}$ \\
\hline Divided Government & $\begin{array}{c}0.0649^{* * *} \\
(0.0229)\end{array}$ & $\begin{array}{c}0.0669^{* * *} \\
(0.0209)\end{array}$ & $\begin{array}{c}0.129^{*} \\
(0.0724)\end{array}$ & $\begin{array}{c}0.0786^{* *} \\
(0.0372)\end{array}$ \\
\hline Demographic Controls (lagged one year) & YES & YES & YES & YES \\
\hline Year FE & YES & YES & YES & YES \\
\hline State FE & YES & YES & YES & YES \\
\hline State Specific Linear Trend & YES & YES & YES & YES \\
\hline Observations & 1,343 & 1,343 & 1,343 & 1,343 \\
\hline R-squared & 0.326 & 0.349 & 0.459 & 0.282 \\
\hline
\end{tabular}




\subsection{Close Elections}

Even when controlling for a wide range of potentially relevant variables in the analysis, some identification concerns may remain. Let me shortly outline three: First, maybe there is no causal relation between divided government and reform, but instead political competion is a relevant omitted variable causing a positive correlation between divided government and reform: States with strong political competition are more likely to implement economic reforms, but are at the same time more likely to end up with divided government. The fixed effects in the previous analyses ensure that the result cannot be driven by differences between states with strong political competition and states with weak political competition (but must be driven by within-states variation). But still, political competition may be a relevant concern. Second, reverse causality may be an issue. Assume that a gubernatorial candidate announces during her electoral campaign that she wants to reform welfare after the election and that voters do want the candidate but do not want welfare to be reformed (which may seem a priori unlikely actually). Voters may then decide to elect the candidate, but to also divide power by electing a state legislature of another partisanship than the gubernatorial candidate. Causality would run from reform intention to divided government in this case. Third, if voters know that divided governments are more (or less) likely to implement reforms, they may vote in such a way to divide (unify) government exactly when they want reforms to be implemented (and vice versa). ${ }^{8}$

To take into account the identification concerns just named, we would ideally need an experiment where some states are randomly assigned a divided and others a unified government. Focusing on close elections comes reasonably close to this ideal. Let us suppose that final election results are random to at least some degree. For example, rain on election day could influence the partisan composition of voters going to the polls. If one - just to fix ideas - further assumes that the state house and the state senate are both dominated by Democratic majorities, the outcome of the gubernatorial race not only determines the partisanship of the future governor, but also if government will be unified or divided. If the gubernatorial election happens to be close enough, the result of the election can be considered random, and thus also the assignment of unified versus divided government. A similar logic applies to state legislative elections and the resulting seat shares determining majority and minority status of the parties in state house and state senate. ${ }^{9}$ Close elections - be it elections for the gubernatorial office or for the legislative chambers - can therefore provide us with quasi-random variation in the assignment of divided versus unified government.

This is why Table 7 looks at close elections. While specifications (1) and (2) replicate the main finding in the full sample (with and without demographic controls), specifications (3) to (6) restrict the sample to cases of close elections. The $10 \%$ sample includes all cases where ex post

\footnotetext{
${ }^{8}$ For a general discussion of endogeneity problems arising when voters take into account the effects of institutions, see Acemoglu (2005).

${ }^{9} \mathrm{I}$ use seat shares of parties in state legislative chambers to measure closeness of majorities in chambers. In principle, one could argue that using election results of individual legislators may be preferable to my approach since even an election that results in a 50\% Democrats and 50\% Republicans seat shares distribution (suggesting a very close race and a random election result) may in principle be perfectly foreseeable if one half of the districts are clearly Democrat and the other half are clearly Republican. But in fact seat shares should be fairly good proxies of the overall closeness of the parties' fight for the majority in a chamber. Besides, Folke and Snyder (2012) argue that seat shares may be preferable to individual vote shares since a relevant share of legislative races at the state level is uncontested which could possibly imply selection bias.
} 
Table 7: Divided Government and Reform in Close Samples

\begin{tabular}{|c|c|c|c|c|c|c|}
\hline & \multicolumn{2}{|c|}{ Full Sample } & \multicolumn{2}{|c|}{$10 \%$ Sample } & \multicolumn{2}{|c|}{$5 \%$ Sample } \\
\hline & (1) & $(2)$ & (3) & $(4)$ & $(5)$ & $(6)$ \\
\hline Divided Government & $\begin{array}{c}0.0600^{* * *} \\
(0.0204)\end{array}$ & $\begin{array}{c}0.0649^{* * *} \\
(0.0229)\end{array}$ & $\begin{array}{c}0.0716^{* *} \\
(0.0297)\end{array}$ & $\begin{array}{c}0.0778^{* *} \\
(0.0308)\end{array}$ & $\begin{array}{c}0.0987^{* *} \\
(0.0472)\end{array}$ & $\begin{array}{l}0.108^{* *} \\
(0.0479)\end{array}$ \\
\hline Demographic Controls (lagged one year) & NO & YES & NO & YES & NO & YES \\
\hline Year FE & YES & YES & YES & YES & YES & YES \\
\hline State FE & YES & YES & YES & YES & YES & YES \\
\hline State Specific Trend & YES & YES & YES & YES & YES & YES \\
\hline Observations & 1,474 & 1,343 & 829 & 760 & 473 & 435 \\
\hline R-squared & 0.315 & 0.326 & 0.354 & 0.381 & 0.435 & 0.467 \\
\hline $\begin{array}{l}\text { Notes: In columns ( } 3) \text { to }(6) \text {, the samples are restr } \\
\text { would be divided or unified was decided by a } 5 \\
\text { Appendix. The dependent variable in all specific } \\
\text { have been introduced in a given state and year. } \\
\text { of the state's lower legislative chamber or the ma } \\
\text { governor. For details regarding any of the variabl } \\
\text { are shown in parentheses. }{ }^{* * *} \mathrm{p}<0.01, * * \mathrm{p}<0.05\end{array}$ & $\begin{array}{l}\text { icted to observa } \\
\text { (10) percentage } \\
\text { ations is a refo } \\
\text { Divided Govern } \\
\text { ajority of the st } \\
\text { es, see the Dat } \\
5 \text { and }{ }^{*} p<0.1 \text {. }\end{array}$ & $\begin{array}{l}\text { tions where th } \\
\text { points or sma } \\
\text { rm dummy th } \\
\text { ment is a dum } \\
\text { ate's upper leg } \\
\text { a Appendix. R }\end{array}$ & $\begin{array}{l}\text { election resu } \\
\text { ler vote/seat } \\
\text { it is equal to } \\
\text { ny that is equ } \\
\text { islative cham } \\
\text { obust standar }\end{array}$ & $\begin{array}{l}\text { lt determinin } \\
\text { margin. For } \\
\text { one if one or } \\
\text { ual to one wh } \\
\text { ber is from a } \\
\text { d errors clus }\end{array}$ & $\begin{array}{l}\text { g whether gov } \\
\text { details, see } \\
\text { more welfare } \\
\text { en either the } \\
\text { nother party } \\
\text { ered at the st }\end{array}$ & $\begin{array}{l}\text { ernment } \\
\text { he RDD } \\
\text { reforms } \\
\text { majority } \\
\text { than the } \\
\text { ate level }\end{array}$ \\
\hline
\end{tabular}

a 10 percentage points or smaller change in the governor vote margin and/or the legislative seat shares would have been sufficient to change treatment from divided to unified government or vice versa. Thus, loosely speaking, the focus is on elections where on the day before the election voters could not know already if government would be divided or unified after the election. One can see that the estimated effect of divided government on reform adoption is significant and between 7 and 8 percentage points. When focusing on even closer elections (where a 5 percentage points or smaller election result change could have induced treatment change), the effect is still significant and between 10 and 11 percentage points. This shows that political competition as omitted variable driving both reforms and divided government cannot explain the finding. If this was the case, one would expect the divided government effect to vanish when restricting attention to competitive situations. On contrary, the estimated coefficient is still significant and even gains in size compared to the full sample case. This suggests the effect of divided government on reform adoption to be even stronger in competitive situations. Overall, looking at close elections with quasi-random treatment assignment clearly illustrates the robustness of the finding of more reform-adoption under divided than under unified government.

An alternative to looking at close elections via sample restrictions like in Table 7 is to conduct a fully-fledged regression discontinuity design (RDD) analysis. However, the divided goverment setting poses two difficulties. First, such an RDD analysis would be non-standard in the sense of having three interdependent treatment assignment variables (election results of governor, house, and senate). This complicates the analysis quite a bit and necessitates even more data than a standard RDD. Second, the data set used in this paper is limited to a maximum of about 1,500 observations. Even for a standard RDD, this would not be much. The results of an RDD analysis reported in the Appendix do nevertheless look reassuring. 


\section{$5 \quad$ Policy Competition as Explanation}

The previous sections have shown that divided governments are more likely to implement welfare reforms compared to unified governments. This does not only contradict conventional wisdom, but is also not in line with standard reasoning in the literature by models such as the one of political inaction by Howitt and Wintrobe (1995) or the veto player theory (Tsebelis (1995), Tsebelis (2002)). The latter, for example, would predict the likelihood of observing a reform to be decreasing in the number of veto players. In contrast to unified governments, in divided governments both parties are veto players. Still, we observe more reforms under divided governments. Why is this the case? - This section sheds some first light on this question.

Policy competition may be the explanation. That political competition matters for US statelevel politics has been shown elsewhere for growth policies (see Besley et al. (2010)) and is also apparent for welfare politics: For example, Table 5 reveals that more polarized Houses reform more and Table 7 shows that the reform effects of divided government get larger when focusing on situations where elections have been very competitive. However, even when restricting the sample to competitively elected governments in Table 7, the effect of divided government on reform adoption stays highly significant. Thus, divided government as such seems to add yet another layer of competition even in competitive situations in general.

Policy Competition. The structural difference between divided and unified government is that under divided government both parties have agenda setting power. This may induce additional policy competition between them which may in the end lead to more reforms being adopted compared to unified governments where one party alone controls the policy agenda. It has been known for a long time that in US states the policy branches (executive versus legislative) engage in competition against each other. The same is true for policy struggle between the legislative chambers (e.g. Rosenthal (2009), p. 197). This policy competition across institutions may be especially strong under divided government, i.e. when these institutions are of different partisanship. For example, it may be politically too expensive for the governor to simply say no to everything that the opposition majority puts on the legislative floor. ${ }^{10}$ Instead he or she may decide to react by a counter reform proposal. The competition may in turn lead to new ideas and finally to new policies. One example of such a policy competition story under divided government could be that the opposition majority leader uses her agenda setting power in the legislature to pass innovative bills in order to qualify as future policymaker and governor in the eyes of the voters. ${ }^{11}$ This also fits the fact that more than one third of all US governors have been members of legislatures before (Gray and Hanson (2008), p. 194).

Case studies on US welfare reforms indeed suggest that policy competition is relevant during the reform process, especially under divided government. Let me illustrate this by giving short examples from four states which all had divided governments when they passed significant welfare reforms: In New York, Republican governor Pataki struggled long and hard with the Democratic state legislature, especially the assembly speaker and the senate president. Together with the governor, the latter two were the "key actors" on welfare reform (Liebschutz (2000),

\footnotetext{
${ }^{10}$ Simple no-saying seems to be rather the exception in US states. See Rosenthal (2009), pp. 266, 271, 272.

${ }^{11}$ For a similar idea, see Mayhew (2005), p. 105. For an illustration of the importance of legislative majority leaders, see Rosenthal (2009), pp. 226 and 236.
} 
pp. 19 and 59). In Florida, Republican senate president Jennings and Democratic governor Chiles were the key leaders to create the Florida WAGES program (Liebschutz (2000), pp. 19 and 38). In New Jersey, the Democratic assembly majority leader Bryant was even the main mover of welfare reform (Haskins (2006), p. 34). And in Wisonsin, the Democratic legislature "attempt[ed] to outdo the governor [Republican reformer Tommy Thompson] in welfare reform" (Wiseman (1996), p. 532). Although the governor was the leader on welfare reform, it was Democratic majorities in the state legislature passing the reforms and sometimes suggesting even more radical reforms than Thompson (Haskins (2006), p. 35 and Liebschutz (2000), p. 109). These examples clearly emphasize the role of competition among parties and their key representatives under divided government. Another fact that may speak in favor of a "positive competition" argument is that reforms implemented under divided government are actually statistically not more likely to be reverted later than reforms passed by unified governments.

The best example of reform competition under divided government is probably the passage of the US Welfare Reform at the federal level in 1996. Although Clinton had campaigned on welfare reform in 1992 and the Democrats controlled both chambers of Congress in 1993 and 1994, not much happened during the first two years of the Clinton administration (Haskins (2006), p. 37). Democrats were themselves divided on the issue of welfare reform, could not agree on a unified proposal, and focused on other agenda items such as health instead (Haskins (2006), p. 39). However, in the November 1994 midterm elections Republicans got a majority in both Senate and House and immediately made use of this newly gained agenda setting power to pass a radical welfare reform bill in January 1995 (Haskins (2006), pp. 20, 192). Although Clinton vetoed the bill in December 1995 (Haskins (2006), p. 253), he was challenged and had to politically react. Republican Speaker Newt Gingrich was a key figure in pushing for welfare reform and negotiating it with Clinton. After yet another veto in January 1996 (Haskins (2006), p. 266), Clinton finally signed a version of the bill in August 1996. The most important welfare reform since the New Deal had been passed under divided government.

If policy competition is indeed the explanation for the divided government effect on reform adoption, one may in fact expect effects of differential size of different types of divided government. For an overview of these different types, consider again Figure 3. Under unified government, all agenda setting power is with one party. Competition should be at its minimum. Under split branch governments, one party has the executive agenda setting power, the other party has full control of the legislative agenda. This may induce policy competition across the two branches. Under split legislature governments, however, competition may be even more intense since policy struggle may now not only take place between branches, but also within the legislature (between the legislative chambers). Following this interpretation of the competition argument, one would expect unified governments to reform the least, split branch governments to reform more, and split legislature governments to reform even more again. This is a prediction one can empirically assess.

Specification (1) of Table 8 does no longer use the divided government dummy as explanatory variable, but instead the two subtypes split branch and split legislature government. The results show that split branch governments are about 5 percentage points and split legislature governments about 9 percentage points more likely to reform than unified governments. 
Table 8: Explaining the Relationship between Divided Government and Reform

\begin{tabular}{|c|c|c|c|c|c|}
\hline $\begin{array}{l}\text { Dependent Variable: } \\
\text { Sample Restriction: }\end{array}$ & $\begin{array}{l}\text { Reform } \\
\text { (1) }\end{array}$ & Dummy & $\begin{array}{c}\text { Reform Package } \\
\text { (3) }\end{array}$ & $\begin{array}{c}\text { Reform D } \\
(4) \\
\text { All Gov. } \\
\text { Any Election }\end{array}$ & $\begin{array}{l}\text { mmy per Govt. } \\
\qquad(5) \\
\text { Reelectable Gov. } \\
\text { Midterm Election }\end{array}$ \\
\hline Split Legislature Dummy & $\begin{array}{c}0.0908^{* *} \\
(0.0346)\end{array}$ & & & & \\
\hline Split Branch Dummy & $\begin{array}{c}0.0529^{* *} \\
(0.0255)\end{array}$ & & & & \\
\hline Divided Government & & $\begin{array}{c}0.0744^{* * * *} \\
(0.0265)\end{array}$ & $\begin{array}{c}0.0223 \\
(0.0368)\end{array}$ & & \\
\hline Divided Government * Gov. Lame Duck & & $\begin{array}{c}-0.0378 \\
(0.0488)\end{array}$ & & & \\
\hline Governor Lame Duck & & $\begin{array}{c}0.0174 \\
(0.0342)\end{array}$ & & & \\
\hline Seat Change in Senate Faction of Governor & & & & $\begin{array}{l}-0.238 \\
(0.180)\end{array}$ & $\begin{array}{l}-1.202 \\
(0.915)\end{array}$ \\
\hline Seat Change in House Faction of Governor & & & & $\begin{array}{l}0.0959 \\
(0.185)\end{array}$ & $\begin{array}{c}1.066 \\
(0.880)\end{array}$ \\
\hline Demographic Controls (lagged one year) & YES & YES & YES & YES & YES \\
\hline Year FE & YES & YES & YES & YES & YES \\
\hline State FE & YES & YES & YES & YES & YES \\
\hline State Specific Linear Trend & YES & YES & YES & YES & YES \\
\hline Observations & 1,343 & 1,343 & 665 & 667 & 229 \\
\hline R-squared & 0.326 & 0.326 & 0.227 & 0.486 & 0.675 \\
\hline \multicolumn{6}{|c|}{$\begin{array}{l}\text { Notes: The dependent variable in all specifications }(1) \text { and }(2) \text { is a reform dummy that is equal to one if one or more welfare reforms have been introduced } \\
\text { in a given state and year. The dependent variable in specification }(3) \text { is a dummy that is equal to one if there was a reform in a given state and year that } \\
\text { included expansive and contractive policy rules changes at the same time. The dependent variable in specifications }(4) \text { and }(5) \text { is a dummy that is equal } \\
\text { to one if one or more welfare reforms have been introduced by a government in a given state. Divided Government is a dummy that is equal to one when } \\
\text { either the majority of the state's lower legislative chamber or the majority of the state's upper legislative chamber is from another party than the governor } \\
\text { Split Branch is equal to one if the governor in a state is confronted with majorities of the opposing party in both legislative chambers. Split Legislature is } \\
\text { equal to one if the majorities in the two legislative chambers in a state are from opposing parties. For details regarding any of the variables, see the Data } \\
\text { Appendix. Robust standard errors clustered at the state level are shown in parentheses. *** p }<0.01 \text {, ** p }<0.05 \text { and *p }<0.1 \text {. }\end{array}$} \\
\hline
\end{tabular}

Although the difference between the two coefficients is not significant, the result is still indicative. Thus, the empirical evidence is at least consistent with the policy competition theory. Next to the policy competition theory, let us also shortly empirically investigate three other potential explanations: a blaming theory, a pet reform theory, and a signaling theory.

Blaming. A blaming theory could go as follows: If a governor implements a reform under unified government, she will be held fully accountable by voters in case the reform happens to fail. If, in contrast, she passes the reform under divided government, she may be able to blame the opposition party for the failed reform. ${ }^{12}$ This way the governor may be able to shift part of the responsibility for a failed reform onto the legislature dominated by the opposition party. This may induce governors to be more willing to suggest reforms under divided government. Under divided government, they are insured against reform failures and do not need to fear to be held fully accountable in terms of votes in the next election.

How does this blaming theory fare empirically? - Note that it should be easier for governors to shift the blame for a failed reform onto the legislature when both legislative chambers are controlled by the other party. We should therefore expect to see more reforms under split branch governments than under split legislature governments. As seen in Table 8 before, this is not the case in the data. Another empirical test of the blaming theory exploits potential differences between reelectable and non-reelectable governors: The above outlined blaming should only

\footnotetext{
${ }^{12}$ See Andersen et al. (2010) on evidence that governors are only punished by voters for late budgets if their party also has a majority in the state legislature. See Alt and Lowry (1994) for similar evidence on fiscal policy.
} 
be relevant for governors who are still afraid of being held accountable by voters for failed policy reforms. Lame duck governors who cannot be reelected anyway should just engage in the reforms they consider best without thinking about how divided governments may insure them against failures. If the blaming theory is correct, we should therefore not expect to see more reforms under divided government in the case of lame duck governors. This is what specification (2) of Table 8 checks by introducing a lame duck control and also an interaction with the divided government dummy. One can see that neither new variable is significant, but the divided government effect is stable. The divided government effect thus seems not to be differential for lame duck governors. ${ }^{13}$ From both empirical checks we can therefore conclude that it is unlikely that a blaming theory can explain the finding. Another issue with this theory is that it could also go the other way round: If a governor is unwilling to reform, she may be more willing not to implement a reform under divided government since she can always (falsely) blame the other party for the reform gridlock.

Pet Reforms. The pet reform theory suggests that each politician has "pet reforms" he or she really wants to implement. Under divided government, more ideologically diverse politicians have a relevant say in policymaking than under unified government. And more ideologically diverse politicians have more ideologically diverse pet reforms. This may lead to more reforms being adopted under divided government. One particular channel could be that under divided government Republicans and Democrats just pack together a rightist change of one policy and a leftist change of another policy into one reform such that each party gets what it wants. "Dirty compromising" could be going on. If this was true, we would expect to see reform packages including at least one leftist policy change and at least one rightist policy change at the same time to be more likely under divided than under unified government. But, in contrast to this theory, specification (3) of Table 8 reveals that divided government does not increase the likelihood of observing such packages.

Signaling. Lastly, this leaves us with the signaling theory. This time, interpret divided government as a result of frustrated voters punishing an incumbent governor for policy disappointments by taking away the governor's majority in the legislature in midterm elections (Alesina and Rosenthal (1995) and Folke and Snyder (2012)). This may signal to the governor that voters are not happy with her performance in office and that the likelihood may be large that voters will not reelect her in the next election. In this desperate situation, the governor may then engage in risky reforming in the hope of being lucky with it and consequently being reelected. If we interpret divided government as a signal to the incumbent governor in this way, we may expect to see more policy reforms under divided than under unified government. ${ }^{14}$

What about empirical evidence consistent with this theory? - Since this theory again relies on governors mainly caring about their reelection prospects, one would again expect to see differences for lame ducks versus reelectable governors. But specification (2) of Table 8 shows that this is not the case. As another check one can directly investigate the reform effect of

\footnotetext{
${ }^{13}$ Bernecker and Gathmann (2013) focuses on governors and their reputational concerns during the US Welfare Reform in greater detail. This analysis includes further factors such as the governor's age or previously hold offices (potentially measuring quality or ambition for higher office), but still finds the positive divided government effect.

${ }^{14} \mathrm{~A}$ similar theory would be that if the governor loses midterm she may ideologically move towards the opposing party in order to get closer to the median voter's bliss point by implementing reforms the opposing party supports. This would also result in more reforms after midterm losses of the governor.
} 
governors losing votes midterm. Specification (4) of Table 8 uses the seat share changes in the senate and house factions of the governor party in the last election as explanatory variables. According to the signaling theory, one should expect a negative relation with reforming: Drops in seat shares should lead to more reforms. However, the estimated coefficients have opposing signs and both are not significant. Specification (5) restricts the sample to reelectable governors who just faced midterm elections, i.e. it focuses on governors who fit exactly the story outlined above. Still, there are no effects. Thus, also the signaling theory is likely not the explanation of the effect of divided government on reform adoption.

Finally, one could also hypothesize that under divided government parties of different partisanship share the political responsibility and that politicians of different partisanship jointly can signal reform necessity to voters in a more credible way than politicians of just one party. The idea would be a bit along the lines of Cukierman and Tommasi (1998) who show that a leftist politician may be more able to credibly signal to voters the necessity of a rightist policy compared to a rightist politician. The better signaling ability of divided governments may then result in more reforms being passed by them compared to unified governments. However, this story is unlikely to be applicable in the case of the US Welfare Reform since there was a broad consensus also among the population that welfare politics needed to change (Mead (2004), p. $8)$.

Summary. In summary, one can at least say that the policy competition theory is consistent with reform case studies and the empirical evidence. The data seem to contradict other potential explanations. However, to get a deeper understanding of what is going on in state-level reform politics and what exactly causes divided government to make reforms more likely, one would need richer data than used for this paper. One first step could be to analyze bill sponsorship and voting on reforms at the individual legislator level. Such data is unfortunately unavailable for most of the time span under consideration and such an analysis is beyond the scope of this paper.

\section{Conclusion}

Conventional wisdom suggests that under divided government political parties block each other resulting in a lack of economic reforms. This paper systematically tests this view by analyzing novel data on welfare policy reforms at the US state level between 1978 and 2010. Panel data estimates show that the probability to implement welfare reforms is in fact between 5 and 10 percentage points higher for states with divided government as opposed to states with unified governments. This effect amounts to 20 to $50 \%$ in size of the unconditional probability to implement a welfare reform and is robust with respect to the inclusion of a wide range of control variables. The effect also keeps its significance and size when using alternative measures of reform, when employing different estimation techniques, and when focusing on close elections providing quasi-random variation in the type of government. One potential conclusion is that in fact voters do not have to worry too much about reform gridlock from electing a divided government. This may be part of the reason why many voters repeatedly prefer divided over unified government not only in elections, but also when being asked about it in polls (Alesina 
and Rosenthal (1995), p. 44).

The finding that divided governments are more likely to reform can potentially be explained by stronger policy competition between governor, senate, and house compared to the case of unified government. The underlying idea is that the opposition party can use the agenda setting power it is endowed with under divided government to confront the governor as key policymaker with policy proposals. Empirical evidence is consistent with the competition theory and inconsistent with other possible explanations of the finding. Case studies evidence also supports the competition theory. But given the limitations of the data set analyzed in this paper further research is definitely needed to shed more light on the explanation of the finding.

Given that more than one half of all US state governments are divided, my results are certainly very relevant in the US context. But, even if a prominent one, it is only one example. In Western democracies in general, unified governments seem to be rather the exception than the rule (Fiorina (1996), p. 111). In France, for instance, the term "cohabitation" is used to describe a very similar phenomenon that occurs when the president faces a majority of an opposing party in parliament and therefore has to appoint a prime minister of this opposing party. Also in many parliamentary democracies different party control of different institutions is often argued to result in blockades which supposedly make reforming impossible. Take the example of Germany where very often the second chamber (consisting of members of state governments) has a different bloc majority than the first chamber (the parliament electing the federal government). Since most important laws need a majority in both chambers, legislative deadlock can possibly arise. Given my result, one may have to rethink common deadlock claims made with respect to divided government also for these and other countries. But further research is needed until any conclusions about reform-making in different political contexts can be drawn.

\section{References}

Acemoglu, D. (2005). Constitutions, politics, and economics: A review essay on persson and tabellini's the economic effects of constitutions. Journal of Economic Literature 43(4), pp. 1025-1048.

Alesina, A. and A. Drazen (1991). Why are stabilizations delayed? The American Economic Review 81(5), pp. 1170-1188.

Alesina, A. and H. Rosenthal (1995). Partisan Politics, Divided Government, and the Economy. Cambridge University Press, New York.

Alesina, A. and H. Rosenthal (1996). A theory of divided government. Econometrica 64(6), pp. 13111341.

Alesina, A. and H. Rosenthal (2000). Polarized platforms and moderate policies with checks and balances. Journal of Public Economics 75(1), pp. 1-20.

Alt, J. E. and R. C. Lowry (1994). Divided government, fiscal institutions, and budget deficits: Evidence from the states. The American Political Science Review 88(4), pp. 811-828.

Andersen, A. L., D. D. Lassen, and L. H. W. Nielsen (2010). Fiscal governance and electoral accountability: Evidence from late budgets. Paper presented at the 2010 Meeting of the American Political Science Association. 
Andersen, A. L., D. D. Lassen, and L. H. W. Nielsen (2012). Late budgets. American Economic Journal: Economic Policy 4(4), pp. 1-40.

Bernecker, A. and C. Gathmann (2013). Trial and error? policy experimentation during the us welfare reform. University of Mannheim Economics Department Working Paper ECON 13-05.

Berry, F. S. and W. D. Berry (1990). State lottery adoptions as policy innovations: An event history analysis. The American Political Science Review 84(2), pp. 395-415.

Berry, F. S. and W. D. Berry (1992). Tax innovation in the states: Capitalizing on political opportunity. American Journal of Political Science 36(3), pp. 715-742.

Berry, F. S. and W. D. Berry (2007). Innovation and diffusion models in policy research. In P. A. Sabatier (Ed.), Theories of the Policy Process, second edition, pp. 223-260. Boulder, CO: Westview.

Berry, W. D., E. J. Ringquist, R. C. Fording, and R. L. Hanson (1998). Measuring citizen and government ideology in the American States, 1960-93. American Journal of Political Science 42(1), pp. 327-348.

Bertrand, M., E. Duflo, and S. Mullainathan (2004). How much should we trust differences-in-differences estimates? The Quarterly Journal of Economics 119(1), pp. 249-275.

Besley, T. and A. Case (1995). Does electoral accountability affect economic policy choices? evidence from gubernatorial term limits. The Quarterly Journal of Economics 110(3), pp. 769-798.

Besley, T. and A. Case (2003). Political institutions and policy choices: Evidence from the united states. Journal of Economic Literature 41(1), pp. 7-73.

Besley, T., T. Persson, and D. M. Sturm (2010). Political competition, policy and growth: Theory and evidence from the us. The Review of Economic Studies 77(4), pp. 1329-1352.

Binder, S. A. (1999). The dynamics of legislative gridlock, 1947-96. The American Political Science Review 93(3), pp. 519-533.

Binder, S. A. (2003). Stalemate: Causes and Consequences of Legislative Gridlock. Washington, DC: Brookings Institution Press.

Binder, S. A. (2011). Legislative productivity and gridlock. In E. Schickler (Ed.), The Oxford Handbook of the American Congress, Chaper 28. Oxford University Press.

Bjørnskov, C. and N. Potrafke (2013). The size and scope of government in the us states: Does party ideology matter? International Tax and Public Finance 20 (4), pp. 687-714.

Blank, R. M. (2002). Evaluating welfare reform in the United States. Journal of Economic Literature 40, pp. 1105-66.

Bowling, C. J. and M. R. Ferguson (2001). Divided government, interest representation, and policy differences: Competing explanations of gridlock in the fifty states. The Journal of Politics 63, pp. $182-206$.

Castanheira, M., G. Nicodeme, and P. Profeta (2012). On the political economics of tax reforms: survey and empirical assessment. International Tax and Public Finance 19(4), pp. 598-624.

Caughey, D. and J. S. Sekhon (2011). Elections and the regression discontinuity design: Lessons from close u.s. house races, 1942-2008. Political Analysis 19(4), pp. 385-408. 
Center for American Women and Politics (2012). Facts on women candidates. http://www.cawp.rutgers.edu/fast_facts/elections/candidates_2010.php.

Center for Economic and Policy Research (2012, Version 1.7). Current Population Survey ORG Uniform Extracts. Washington, D.C.

Chari, V. V., L. E. Jones, and R. Marimon (1997). The economics of split-ticket voting in representative democracies. The American Economic Review 87(5), pp. 957-976.

Chattopadhyay, R. and E. Duflo (2004). Women as policy makers: Evidence from a randomized policy experiment in india. Econometrica 72(5), pp. 1409-1443.

Crouse, G. (1999). Implementation of major changes to welfare policies, 1992-1998. http://aspe.hhs.gov/hsp/waiver-policies99/policy_cea.htm.

Cukierman, A. and M. Tommasi (1998). When does it take a nixon to go to china? The American Economic Review 88(1), pp. 180-197.

Cutler, L. N. (1988). Some reflections about divided government. Presidential Studies Quarterly 18(3), pp. $485-492$.

Dell, M. (2010). The persistent effects of peru's mining mita. Econometrica 78(6), pp. 1863-1903.

Dewatripont, M. and G. Roland (1995). The design of reform packages under uncertainty. The American Economic Review 85(5), pp. 1207-1223.

Eggers, A. C., O. Folke, A. Fowler, J. Hainmueller, A. B. Hall, and J. M. Snyder (May 2013). On the validity of the regression discontinuity design for estimating electoral effects: New evidence from over 40,000 close races. Working Paper.

Fang, H. and M. P. Keane (2004). Assessing the impact of welfare reform on single mothers. Brookings Papers on Economic Activity 1, pp. 1-116.

Fellowes, M. C. and G. Rowe (2004). Politics and the new american welfare states. American Journal of Political Science 48(2), pp. 362-373.

Fernandez, R. and D. Rodrik (1991). Resistance to reform: Status quo bias in the presence of individualspecific uncertainty. The American Economic Review 81(5), pp. 1146-1155.

Ferreira, F. and J. Gyourko (2009). Do political parties matter? evidence from u.s. cities. The Quarterly Journal of Economics 124(1), pp. 399-422.

Fiorina, M. (1996). Divided Government (second ed.). Allyn \& Bacon.

Folke, O. and J. M. Snyder (2012). Gubernatorial midterm slumps. American Journal of Political Science 56(4), pp. 931-948.

Fox, J. and R. V. Weelden (2010). Partisanship and the effectiveness of oversight. Journal of Public Economics 94(9-10), pp. 674-687.

Funk, P. and C. Gathmann (2014). Gender gaps in policy preferences: Evidence from direct democracy in switzerland. Economic Policy, forthcoming.

Gray, V. and R. L. Hanson (Eds.) (2008). Politics in the American States: A Comparative Analysis (ninth ed.). CQ Press, Washington D.C. 
Han, W.-J., C. Ruhm, and J. Waldfogel (2009). Parental leave policies and parents' employment and leave-taking. Journal of Policy Analysis and Management 28(1), pp. 29-54.

Harvey, C., M. J. Camasso, and R. Jagannathan (2000). Evaluating welfare reform waivers under section 1115. The Journal of Economic Perspectives 14(4), pp. 165-188.

Haskins, R. (2006). Work Over Welfare: The Inside Story of the 1996 Welfare Reform Law. Washington DC: The Brookings Institution.

Howitt, P. and R. Wintrobe (1995). The political economy of inaction. Journal of Public Economics 56(3), pp. 329-353.

Hoxby, C. M. (2000). The effects of class size on student achievement: New evidence from population variation. The Quarterly Journal of Economics 115(4), pp. 1239-1285.

Imbens, G. and T. Zajonc (2011). Regression discontinuity design with multiple forcing variables. Working Paper.

Imbens, G. W. and T. Lemieux (2008). Regression discontinuity designs: A guide to practice. Journal of Econometrics 142(2), pp. 615-635.

Jacobson, G. C. (1990). The electoral origins of divided government: Competition in US House elections, 1946-1988. Boulder: Westview Press.

Klarner, C. (2003). The measurement of the partisan balance of state government. State Politics E Policy Quarterly 3(3), pp. 309-319.

Klarner, C. E., J. H. Phillips, and M. Muckler (2012). Overcoming fiscal gridlock: Institutions and budget bargaining. Journal of Politics 74(4), pp. 992-1009.

Koerper, K. (1996). Weekly tracking update - welfare reform: Section 1115 Waiver Activity. Office of Planning, Research and Evaluation.

Lee, D. S. (2008). Randomized experiments from non-random selection in u.s. house elections. Journal of Econometrics 142(2), pp. 675-697.

Lee, D. S. and T. Lemieux (2010). Regression discontinuity designs in economics. Journal of Economic Literature 48(2), pp. 281-355.

Lee, D. S., E. Moretti, and M. J. Butler (2004). Do voters affect or elect policies? evidence from the u. s. house. The Quarterly Journal of Economics 119(3), pp. 807-859.

Leip, D. (2012). Dave Leip's Atlas of U.S. Presidential Elections. http://www.uselectionatlas.org.

Lieberman, R. C. and G. M. Shaw (2000). Looking inward, looking outward: The politics of state welfare innovation under devolution. Political Research Quarterly 53(2), pp. 215-240.

Liebschutz, S. F. (Ed.) (2000). Managing Welfare Reform in Five States. Rockefeller Institute Press.

List, J. A. and D. M. Sturm (2006). How elections matter: Theory and evidence from environmental policy. Quarterly Journal of Economics 121(4), pp. 1249-1281.

Lott, J. R. and L. W. Kenny (1999). Did women's suffrage change the size and scope of government? Journal of Political Economy 107(6), pp. 1163-1198. 
Mayhew, D. R. (2005). Divided We Govern. Party Control, Lawmaking, and Institutions, 1946 -2002 (second ed.). Yale University Press, New Haven and London.

Mead, L. M. (2004). Government Matters. Princeton University Press.

Moffitt, R. A. (2002). Welfare Benefits File. http://www.econ.jhu.edu/People/Moffitt.

Papay, J. P., J. B. Willett, and R. J. Murnane (2011). Extending the regression-discontinuity approach to multiple assignment variables. Journal of Econometrics 161(2), pp. 203-207.

Pettersson-Lidbom, P. (2008). Do parties matter for economic outcomes? a regression-discontinuity approach. Journal of the European Economic Association 6(5), pp. 1037-1056.

Pettersson-Lidbom, P. (2012). Does the size of the legislature affect the size of government? evidence from two natural experiments. Journal of Public Economics 96(3-4), pp. 269-278.

Poterba, J. M. (1994). State responses to fiscal crises: The effects of budgetary institutions and politics. Journal of Political Economy 102(4), pp. 799-821.

Rogers, J. R. (2005). The impact of divided government on legislative production. Public Choice 123(1/2), pp. 217-233.

Rosenthal, A. (2009). Engines of Democracy: Politics and Policymaking in State Legislatures. CQ Press, Washington D.C.

Roubini, N. and J. D. Sachs (1989). Political and economic determinants of budget deficits in the industrial democracies. European Economic Review 33(5), pp. 903-933.

Royed, T. J. and S. A. Borrelli (1997). Political parties and public policy: Social welfare policy from carter to bush. Polity 29(4), pp. 539-563.

Schelker, M. (March 2012). Lame ducks and divided government: How voters control the unaccountable. CESifo Working Paper No. 3523.

Schram, S. F., J. Soss, and R. C. Fording (Eds.) (2003). Race and the Politics of Welfare Reform. Ann Arbor, MI: University of Michigan Press.

Shipan, C. R. (2006). Does divided government increase the size of the legislative agenda? In E. S. Adler and J. S. Lapinski (Eds.), The Macropolitics of Congress, Chapter 6. Princeton University Press.

Snyder, J., O. Folke, and S. Hirano (May 2012). Partisan imbalance in regression discontinuity studies based on electoral thresholds. Working Paper.

Soss, J., R. C. Fording, and S. F. Schram (2008). The color of devolution: Race, federalism, and the politics of social control. American Journal of Political Science 52(3), pp. 536-553.

Soss, J., S. F. Schram, T. P. Vartanian, and E. O'Brien (2001). Setting the terms of relief: Explaining state policy choices in the devolution revolution. American Journal of Political Science 45(2), pp. 378-395.

Sundquist, J. L. (1988). Needed: A political theory for the new era of coalition government in the united states. Political Science Quarterly 103(4), pp. 613-635.

The Economist (2012). November 10th Issue, title page. 
Tsebelis, G. (1995). Decision making in political systems: Veto players in presidentialism, parliamentarism, multicameralism and multipartyism. British Journal of Political Science 25(03), pp. 289-325.

Tsebelis, G. (2002). Veto Players: How Political Institutions Work. Princeton University Press.

U. S. Department of Homeland Security (2011). Yearbook of Immigration Statistics. Washington, D.C.: Office of Immigration Statistics.

United States Census Bureau (2011). Statistical Abstract of the United States: 2012 (131st edition).

Urban Institute (2012). Welfare Rules Database. Washington, D.C.

US Government Spending (2013). Spending by states.

http://www.usgovernmentspending.com/compare_state_spending_2010p40c.

Walker, J. L. (1969). The diffusion of innovations among the American States. American Political Science Review 63(3), pp. 880-899.

Weissert, C. S. (2000). Learning from the midwestern leaders. In C. S. Weissert (Ed.), Learning from the Leaders: Welfare Reform Politics and Policy in Five Midwestern States, Chapter 1, Albany, NY. Rockefeller Institute Press.

Wiseman, M. (1996). State strategies for welfare reform: The wisconsin story. Journal of Policy Analysis and Management 15(4), pp. 515-546.

\section{A Maps}

The following two maps (Figures 5 and 6) show the share of years between 1978 and 2010 in which a state reformed the welfare system and in which a state had a divided government. The darker the color the stronger the incidence.

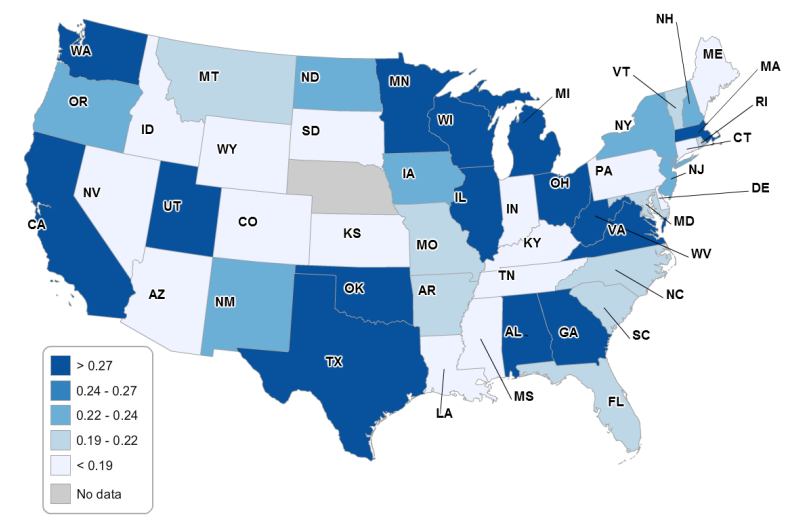

Figure 5: Reform Incidence

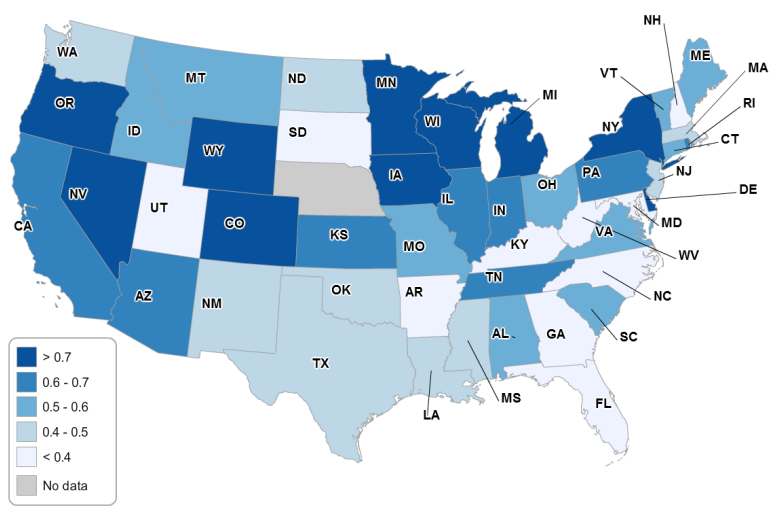

Figure 6: Divided Government Incidence

\section{B Differential Effects in Different Samples}

Electoral Cycles and Government History. This section explores the robustness of the result across different sample restrictions. The first restriction is using electoral cycles as units of observation instead of years. This roughly cuts the sample into half since usually every other year there is at least a 
legislative election in most states. The reason to look at electoral cyles as a robustness check is that under divided government reform-making may be staggered across several years leading to a correlation between divided government and reform years. The mechanism could be as follows: A unified government can easily implement a welfare reform in its first year in office since it is not confronted with any institutional obstacles, while a divided government has to struggle more, gets blocked, and consequently implements only a part of the reform in the first year and a second part in the second year in office. Since the unit of observation in the baseline analysis is state-years, the reform dummy would be equal to one for the first year for the unified government, but would be equal to one for both the first and the second year for the divided government. Although the two governments may in fact have implemented the very same reform, the differences in timing may make the divided government look more reformist in the analysis.

This is what Appendix Table 9 investigates by looking at whole electoral cycles instead of years, i.e. the reform dummy is now defined on the level of governments and no longer on a yearly basis. Specification (1) shows that the effect of divided government is still sizable and significant. The finding is thus not driven by differences in reform timing and the mechanism outlined in the preceding paragraph cannot account for it. Table 8 also checks on the level of governments if the divided government effect is differential depending on the previous government. One could, for example, imagine a divided government to be more likely to reform when it follows on a unified Democratic government which tried to keep the status quo. Or a divided government could be more likely to reform when the previous government also had been divided and the party leaders are already used to the situation of non-unified partisanship. Specifications (2) to (4) reveal that no such differential effects can be identified. Thus, it seems that divided government per se has an enhancing effect on reform adoption - irrespectively of the past form of government. Specification (5) looks at how the effect may be different depending on how a divided government came to power - via general elections (when the governor is up for election) or via midterm elections (when the governor is not up for election). About one third of the changes from unified to divided government are the result of midterm elections, while two thirds result from general elections. As can be seen from specification (5), the estimated coefficients' sizes are different, but not statistically significant. One can therefore not conclude that the divided government effect was solely driven by general or by midterm elections.

Table 9: Divided Government, Government History and Reform

\begin{tabular}{|c|c|c|c|c|c|}
\hline & (1) & $(2)$ & $(3)$ & $(4)$ & $(5)$ \\
\hline Divided Government & $\begin{array}{c}0.0899^{* *} \\
(0.0406)\end{array}$ & & & & \\
\hline Divided Govt. with past Unified Govt. & & $\begin{array}{c}0.0834 \\
(0.0603)\end{array}$ & & & \\
\hline Divided Govt. with past Divided Govt. & & $\begin{array}{c}0.0698 \\
(0.0507)\end{array}$ & & $\begin{array}{c}0.0697 \\
(0.0510)\end{array}$ & \\
\hline Divided Govt. with past Unified Dem. Govt. & & & $\begin{array}{c}0.0611 \\
(0.0813)\end{array}$ & $\begin{array}{c}0.0883 \\
(0.0812)\end{array}$ & \\
\hline Divided Govt. with past Unified Rep. Govt. & & & $\begin{array}{c}0.0409 \\
(0.0613)\end{array}$ & $\begin{array}{c}0.0730 \\
(0.0711)\end{array}$ & \\
\hline New Divided Govt. via General Elections & & & & & $\begin{array}{c}0.0334 \\
(0.0772)\end{array}$ \\
\hline New Divided Govt. via Midterm Elections & & & & & $\begin{array}{c}0.101 \\
(0.0884)\end{array}$ \\
\hline Demographic Controls (lagged one year) & YES & YES & YES & YES & YES \\
\hline Year FE & YES & YES & YES & YES & YES \\
\hline State FE & YES & YES & YES & YES & YES \\
\hline State Specific Linear Trend & YES & YES & YES & YES & YES \\
\hline Observations & 651 & 651 & 651 & 651 & 651 \\
\hline R-squared & 0.489 & 0.487 & 0.484 & 0.487 & 0.485 \\
\hline
\end{tabular}

Notes: The dependent variable in all specifications is a reform dummy that is equal to one if one or more welfare reforms have been introduced in a given state by a given government. Divided Government is a dummy that is equal to one when either the majority of the state's lower legislative chamber or the majority of the state's upper legislative chamber is from another party than the governor. For details regarding any of the variables, see the Data Appendix. Robust standard errors clustered at the state level are shown in parentheses. ${ }^{* * *} \mathrm{p}<0.01,{ }^{* *} \mathrm{p}<0.05$ and ${ }^{*} \mathrm{p}<0.1$. 
Space and Time. Appendix Table 10 differentiates the effect of divided government on the likelihood of reform adoption across space and time. Specification (1) shows the baseline specification from before. Specification (2) adds an interaction for Southern states. This allows the South of the US - which is commonly known to be potentially politically different compared to the rest of the US - to be different with respect to the effect of divided government on reform. It turns out that this seems not to be important: The coefficient of the interaction term is small and not significant. Specification (3) adds an interaction with a dummy that is equal to one for all years after 1996 when the landmark Welfare Reform under President Clinton was implemented. As outlined before, this reform fundamentally changed welfare politics in the US. The estimation results show that the effect is not statistically different before and after the 1996 Welfare Reform. The positive coefficient of the interaction term seems to suggest that the divided government effect is a bit larger after 1996, but this can be explained by the fact that also the unconditional propensity to reform welfare in a given year is larger after 1996. Moreover, statistical power is not sufficient to identify the divided government effect separately for the two time periods. Specification (4), finally, separates the highly reformist Clinton era (1992-2000) from the Non-Clinton era. Although, the interaction effect for the non-Clinton era is statistically not significant, the negative sign seems to suggest that the divided gpvernment effect may have been indeed stronger during the presidency of Clinton.

Table 10: Divided Government and Reform in Different Samples

\begin{tabular}{|c|c|c|c|c|}
\hline & (1) & $(2)$ & (3) & $(4)$ \\
\hline Divided Government & $\begin{array}{c}0.0649^{* * *} \\
(0.0229)\end{array}$ & $\begin{array}{c}0.0764^{* *} \\
(0.0315)\end{array}$ & $\begin{array}{c}0.0535 \\
(0.0342)\end{array}$ & $\begin{array}{l}0.105^{* *} \\
(0.0459)\end{array}$ \\
\hline Divided Government $*$ Southern State & & $\begin{array}{l}-0.0325 \\
(0.0442)\end{array}$ & & \\
\hline Divided Government * After 1996 Dummy & & & $\begin{array}{c}0.0248 \\
(0.0627)\end{array}$ & \\
\hline Divided Government $*$ Non-Clinton Era & & & & $\begin{array}{l}-0.0578 \\
(0.0457)\end{array}$ \\
\hline Demographic Controls (lagged one year) & YES & YES & YES & YES \\
\hline Year FE & YES & YES & YES & YES \\
\hline State FE & YES & YES & YES & YES \\
\hline State Specific Linear Trend & YES & YES & YES & YES \\
\hline Observations & 1,343 & 1,343 & 1,343 & 1,343 \\
\hline R-squared & 0.326 & 0.326 & 0.326 & 0.326 \\
\hline \multicolumn{5}{|c|}{$\begin{array}{l}\text { Notes: The dependent variable in all specifications is a reform dummy that is equal to one if one or more welfare } \\
\text { reforms have been introduced in a given state and year. Divided Government is a dummy that is equal to one } \\
\text { when either the majority of the state's lower legislative chamber or the majority of the state's upper legislative } \\
\text { chamber is from another party than the governor. For details regarding any of the variables, see the Data } \\
\text { Appendix. Robust standard errors clustered at the state level are shown in parentheses. }{ }^{* * *} \mathrm{p}<0.01,{ }^{* *} \mathrm{p}<0.05 \\
\text { and }{ }^{*} \mathrm{p}<0.1 \text {. }\end{array}$} \\
\hline
\end{tabular}

\section{Further Robustness Checks}

This section shows some further robustness checks. Appendix Table 11 illustrates that the baseline results presented in Table 2 are robust with respect to esimating logit instead of linear probability models. The estimated odds ratio is about 1.5, meaning that divided governments are about $50 \%$ more likely to reform than unified governments.

Appendix Table 12 shows that the ideology robustness results from Table 4 also hold when restricting attention to only contractive welfare reforms. The smaller coefficient in Appendix Table 12 compared to Table 4 can be explained by the fact that also the unconditional reform probability is lower when focusing on contractive reforms only. Expansive reforms are empirically irrelevant before 1996, and even after 1996 they do account for less than $25 \%$ of all reforms.

Appendix Table 13 uses Arellano-Bond estimation to lend further credibility to the robustness results with respect to the reform history presented in Table 5. 
Appendix Table 14 shows that the divided government effect is also present when using count variables reform measures and Poisson estimation.

Table 11: Divided Government and Reform (Logit Estimation)

\begin{tabular}{|c|c|c|}
\hline & (1) & $(2)$ \\
\hline Divided Government (Odds Ratio) & $\begin{array}{c}1.534^{* *} \\
(0.254)\end{array}$ & $\begin{array}{c}1.597^{* * *} \\
(0.286)\end{array}$ \\
\hline Demographic Controls & NO & YES \\
\hline Year FE & YES & YES \\
\hline State FE & YES & YES \\
\hline Observations & 1,474 & 1,343 \\
\hline Pseudo R-squared & 0.400 & 0.468 \\
\hline
\end{tabular}

Table 12: Divided Government, Ideology and Reform (Narrow Contractive Reform 1978-2010)

\begin{tabular}{|c|c|c|c|c|c|c|c|c|}
\hline Dependent Variable: Narrow Reform Dummy & (1) & $(2)$ & (3) & $(4)$ & (5) & $(6)$ & $(7)$ & (8) \\
\hline Divided Government & $\begin{array}{c}0.0408^{* *} \\
(0.0200)\end{array}$ & $\begin{array}{c}0.0408^{* *} \\
(0.0201)\end{array}$ & $\begin{array}{l}0.0403^{*} \\
(0.0201)\end{array}$ & $\begin{array}{c}0.0439^{* *} \\
(0.0195)\end{array}$ & $\begin{array}{c}0.0476^{* *} \\
(0.0215)\end{array}$ & $\begin{array}{c}0.0395^{* *} \\
(0.0196)\end{array}$ & $\begin{array}{c}0.0555^{* *} \\
(0.0235)\end{array}$ & $\begin{array}{c}0.0862^{\text {** }} \\
(0.0387)\end{array}$ \\
\hline \% Dem. Votes Last Presidential Election (/1000) & $\begin{array}{l}-1.657 \\
(3.089)\end{array}$ & & & & & & $\begin{array}{c}-1.221 \\
(3.330)\end{array}$ & \\
\hline Citizens Ideology (Berry et al. 1998) (/1000) & & $\begin{array}{c}1.367 \\
(2.078)\end{array}$ & & & & & $\begin{array}{c}2.708 \\
(2.883)\end{array}$ & \\
\hline Dem. Seat Share Senate & & & $\begin{array}{c}-0.0742 \\
(0.168)\end{array}$ & $\begin{array}{c}-0.444^{*} \\
(0.229)\end{array}$ & & & $\begin{array}{l}-0.410^{*} \\
(0.238)\end{array}$ & \\
\hline Dem. Seat Share House & & & $\begin{array}{l}0.0367 \\
(0.208)\end{array}$ & $\begin{array}{c}0.189 \\
(0.240)\end{array}$ & & & $\begin{array}{c}0.163 \\
(0.250)\end{array}$ & \\
\hline Dem. Seat Share Senate * Dem. Senate Maj. & & & & $\begin{array}{c}0.197^{* *} \\
(0.0941)\end{array}$ & & & $\begin{array}{c}0.208^{* *} \\
(0.102)\end{array}$ & \\
\hline Dem. Seat Share House * Dem. House Maj. & & & & $\begin{array}{c}-0.0622 \\
(0.0748)\end{array}$ & & & $\begin{array}{l}-0.0339 \\
(0.0841)\end{array}$ & \\
\hline Government Ideology (Berry et al. 1998) (/1000) & & & & & $\begin{array}{l}-0.0977 \\
(0.650)\end{array}$ & & $\begin{array}{l}-1.213 \\
(1.492)\end{array}$ & \\
\hline Governor Democrat $(0=$ Republican $)$ & & & & & & $\begin{array}{c}-0.00529 \\
(0.0200)\end{array}$ & $\begin{array}{c}0.0313 \\
(0.0463)\end{array}$ & $\begin{array}{c}0.0476 \\
(0.0442)\end{array}$ \\
\hline Divided Government * Governor Democrat & & & & & & & & $\begin{array}{c}-0.0872 \\
(0.0605)\end{array}$ \\
\hline Year FE & YES & YES & YES & YES & YES & YES & YES & YES \\
\hline State FE & YES & YES & YES & YES & YES & YES & YES & YES \\
\hline State Specific Linear Trend & YES & YES & YES & YES & YES & YES & YES & YES \\
\hline Observations & 1,474 & 1,474 & 1,474 & 1,474 & 1,383 & 1,474 & 1,383 & 1,474 \\
\hline R-squared & 0.291 & 0.291 & 0.291 & 0.294 & 0.295 & 0.291 & 0.298 & 0.292 \\
\hline
\end{tabular}


Table 13: Divided Government and Reform History (Arellano-Bond Estimation)

$(1)$

(2)

(3)

Divided Government
Reform Dummy (t-1)
Reform Dummy (t-2)
Reform Dummy ( $t-3)$

$0.0819^{* *} \quad 0.0837^{*}$

$(0.0403) \quad(0.0440)$

$0.00306 \quad 0.0302$

$(0.0612) \quad(0.0976)$

0.0334

$(0.0764)$

$0.0868^{*}$

$(0.0480)$

$-0.00199$

$(0.115)$

$-0.0141$

$(0.0822)$

$-0.0713$

(0.0597)

Demographic Controls (lagged one year)

Max. lag of dep. variable used as instrument

$\begin{array}{cc}\text { YES } & \text { YES } \\ 4 & 5\end{array}$

YES

6

Observations

$\begin{array}{ll}1.342 & 1.342 \\ 46.07 & 52.08\end{array}$

1.342

Wald Chi Square Statistic

52.08

32.24

Notes: The dependent variable in all specifications is a reform dummy that is equal to one if one or more welfare reforms have been introduced in a given state and year. Divided Government is a dummy that is equal to one when either the majority of the state's lower legislative chamber or the majority of the state's upper legislative chamber is from another party than the governor. For details regarding any of the variables, see the Data Appendix. Standard errors clustered at the state level are shown in parentheses. ${ }^{* * *} \mathrm{p}<0.01,{ }^{* *} \mathrm{p}<0.05$ and $* \mathrm{p}<0.1$.

Table 14: Divided Government and Count Measures of Reform (Poisson Est.)

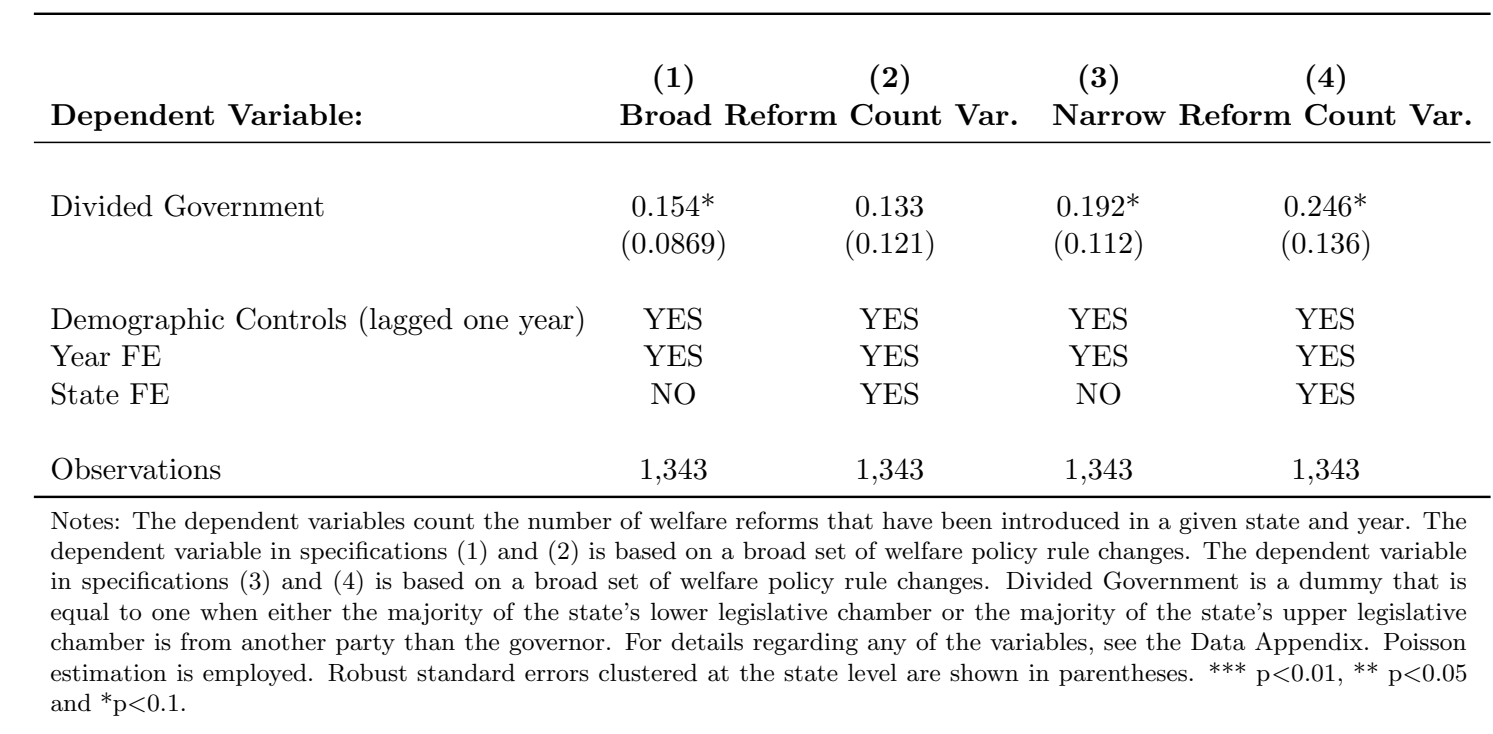




\section{RDD}

The section presents a short RDD analysis of the effect of divided government on reform adoption. Compared to the panel data analysis, the main difference in terms of idenficiation is to exploit deeper knowledge about the selection rule determining treatment. In particular, the RDD uses the fact that treatment (divided versus unified government) changes discontinuously in election results (of governors, state houses, and state senates). Focusing on close elections provides us with quasi-experimental treatment assignment. RDD's "randomized variation is a consequence of agents' inability to precisely control the assignment variable near the known cutoff" (Lee (2008), p. 282), i.e. in this setting the many voters' inability to perfectly manage the joint election result makes the institutional setting "quasirandom". Because of the interplay of three different institutions determining treatment, I have three interdependent assignment variables in this RDD. This is non-standard and I have to adjust the design as explained below. Since this complication causes a need of many observations, this RDD analysis should be considered only complementary to the panel data analysis presented before. The remainder of this RDD section first shortly reviews the political economy RDD literature, then explains in a detailed way how to deal with the interdependent assignment variables in the divided government setting, then covers the identifying assumptions of this RDD, and finally presents some results.

\section{D.1 Literature}

The idea to use an RDD in an electoral context has first been explored by Lee et al. (2004) and PetterssonLidbom (2008). While the former analyzes the effect of electoral strength on subsequent roll-call voting, the latter investigates the effect of party ideology on policy-making. The idea has for example also been used by Lee (2008), Ferreira and Gyourko (2009), and Pettersson-Lidbom (2012). Lee (2008) investigates the incumbency advantage in politics, Ferreira and Gyourko (2009) the effect of party control on policies in US cities, and Pettersson-Lidbom (2012) the effect of legislature size on government size.

For nice reviews of papers using close elections RDD, see Caughey and Sekhon (2011) and Snyder et al. (2012). Caughey and Sekhon (2011) argue that elections RDD may be problematic since close winners may often differ in pretreatment covariates compared to close losers in US House elections due to manipulation around the threshold. But they admit that the problem is less severe at the state level where races are often less professionalized. They also propose to check effects on lagged response variables in the RDD (which I do). Snyder et al. (2012), on the other hand, show that covariate imbalances across the election threshold occur even without any sorting around the threshold simply due to the underlying distribution of partisanship in the electorate. According to their view, these imbalances do not pose any problems to elections RDD as long as a polynomial of the forcing variable is included (which I do as well). Furthermore, Eggers et al. (2013) show that problematic imbalances seem to be a US House anomaly during the period after WWII. Investigating more than 40,000 close races in several countries, they do not find imbalances in any other electoral context (including, for example, US statewide and state legislative elections). For general practical RDD introductions, see Imbens and Lemieux (2008) and Lee and Lemieux (2010).

The RDD in this paper is special since it is characterized by several interdependent treatment assignment variables. For theoretical treatments of this and similar topics, see Imbens and Zajonc (2011) and Papay et al. (2011). See Dell (2010) for a recent application to a case with two independent assignment variables.

\section{D.2 Multiple Interdependent Assignment Variables}

The setting is non-standard since it is characterized by three interdependent assignment variables: the election result of the gubernatorial race and the two seat shares for the two legislative chambers resulting from the legislative elections. These three election results jointly determine if government is divided or unified in a state. When multiple variables are responsible for treatment assignment and only the average treatment effect is of interest, the most straightforward approach is to collapse the multiple variables into one single (artificial) assignment variable taking the value of the one of the original assignment variables which has the value that is closest to the treatment boundary (as suggested by Imbens and Zajonc (2011)). This makes the RDD unidimensional again by treating the closest distance to the treatment boundary as assignment variable. The new assignment variable therefore measures the closeness of the closest election that could have changed treatment (from divided government to unified or vice versa) if the election had resulted in the other party winning. Since in this analysis the interest indeed lies 
in identifying the average effect (of divided versus unified government), the assignment variables are collapsed in the described way. The collapsing procedure is explained next.

The goal is to reduce the dimensionality of assignment from three to one to be able to analyze the setting using the standard univariate regression discontinuity framework. Therefore, the three assignment variables have to be collapsed into one. The treatment of interest is divided versus unified government. Unified government refers to a situation when the governor, the majority of legislators in the house, and the majority of legislators in the senate are all from the same party. Divided government refers to all other cases. The three institutions determining treatment therefore are governor, house, and senate. The three variables determining treatment assignment are the election results for these three institutions. We seek to identify exogenous variation in the treatment, i.e. we want to focus the analysis on elections that fulfill two criteria: First, they had the potential to change treatment from divided to unified or vice versa. Second, they were close in the sense that it was not entirely clear to voters beforehand which party would win the election. An election that does not fulfill the first criterion would be the election of a state senate when the governor's office and the house are not up for election, the governor is a Republican, and the senate is Democrat (meaning having a Democratic majority). In that case, regardless of the outcome of the house election the future government will be divided since incumbent governor and senate majority are not from the same party. There is no way the house election can produce a unified government. In contrast, all elections where the election has the potential to theoretically result in both treatments fulfill the first criterion, have the potential to provide us with quasi-random treatment assignment, and are included in the regression discontinuity analysis. For all those elections, the closeness to the treatment boundary (where divided changes to unified government or vice versa) is determined and assigned as value of the new assignment variable. The creation of the new assignment variable is illustrated using some examples in the following paragraph.

The most common electoral structure in US states is to elect governor, senate, and house on the same day every four years and to additionally elect the house and the senate (but not the governor) after two years since state legislators are usually elected for two years only. The second type of elections (when only house and senate are elected) are usually called "midterm elections" since they take place in the mid of the term of the governor (who is in office for four years). There are states with different electoral structures and all these different structures are taken into account when coding the new assignment variable, but the just presented structure is by far most common in US states. In the sample from 1978 to 2010, there are more than 400 elections of the first type (governor, house, and senate up for election) and more than 300 elections of the midterm type (house and senate up for election). But there are only between 1 and 40 elections of any other type. The creation of the new assignment variable proceeds in 6 steps for every election day in every state between 1978 and 2010. The steps are:

(1) Check which of the three institutions (governor, house, senate) are up for election on the election day under consideration.

(2) Determine party control of those institutions that are not up for election.

(3) Determine if the election day can potentially change treatment from divided government to unified government or vice versa. If yes, determine which of the elections (of which institutions) can change treatment.

(4) For those elections that can change treatment determine the value of the (multiple) assignment variables, i.e. the election results. For governors, this is the vote margin. For legislatures, this is the deviation of the Democratic seat share from 0.5..$^{15}$

(5) Assign the smallest value of these assignment variables from step (4) that would have been sufficient for a treatment change to the new (to be created) assignment variable.

(6) Extend the new assignment variable as a measure of closeness to the treatment boundary to all following years until the next election takes place.

Let us have a look at some examples for midterm elections. The logic for elections where other combinations of institutions are up for elections is similar.

Example 1: Suppose we are confronted with a standard midterm election day where senate and house are up for election. Let us suppose that the incumbent governor who is not up for election is a Republican. Let us further suppose that both house and senate happen to get a Republican majority in the current election. Government is unified. Clearly, both elections (the house and the senate election) had the theoretical potential of having assigned a divided government treatment instead of a unified

\footnotetext{
${ }^{15}$ The usually very small number of independent legislators are split equally between Republicans and Democrats when calculating seat shares.
} 
government treatment (if they had resulted in the Democrats winning a majority). If in only one of the two legislative elections the Democrats had gained a majority, government would have been divided. The new treatment assignment variable will be assigned the assignment variable of house or senate depending on which election was closer.

Example 2: Suppose we are confronted with a standard midterm election day where senate and house are up for election. Let us suppose that the incumbent governor who is not up for election is a Republican. Let us further suppose that the senate happens to get a Democratic majority in the current election, the house happens to get a Republican majority. Government therefore is divided. In this case, only the senate election had the theoretical potential of changing the treatment to unified government. If the house election had resulted in a Democratic majority, this would have not changed treatment. The new treatment assignment variable will therefore be assigned the assignment variable of the senate.

Example 3: Suppose we are confronted with a standard midterm election day where senate and house are up for election. Let us suppose that the incumbent governor who is not up for election is a Republican. Let us further suppose that both house and senate happen to get a Democratic majority in the current election. Government is divided. Clearly, only both elections together had the potential of having resulted in unified government instead had they both resulted in a Republican majority. The new treatment assignment variable will therefore be assigned the sum of the assignment variables of the house and the senate election.

\section{D.3 Identifying Assumptions}

The important identifying assumptions of the approach are the following. First, there has to be some randomness in final election results. This seems obvious. Second, there must not be any sorting around the discontinuity, i.e. there must not be any manipulation of election results by candidates close to the threshold. This second assumption is checked by investigating the smoothness of the density of observations around the threshold and by testing the similarity of relevant pretreatment observables across the threshold. Figure 7 shows that the density of the closeness assignment variable is indeed smooth at zero and manipulation around the cutoff should not be of any concern in this analysis. Appendix Table 15 and Appendix Table 16 show that treatment and control group are similar in terms of predetermined covariates when focusing on observations close to the threshold (i.e. close elections).

Figure 7: Distribution of the RDD Assignment Variable

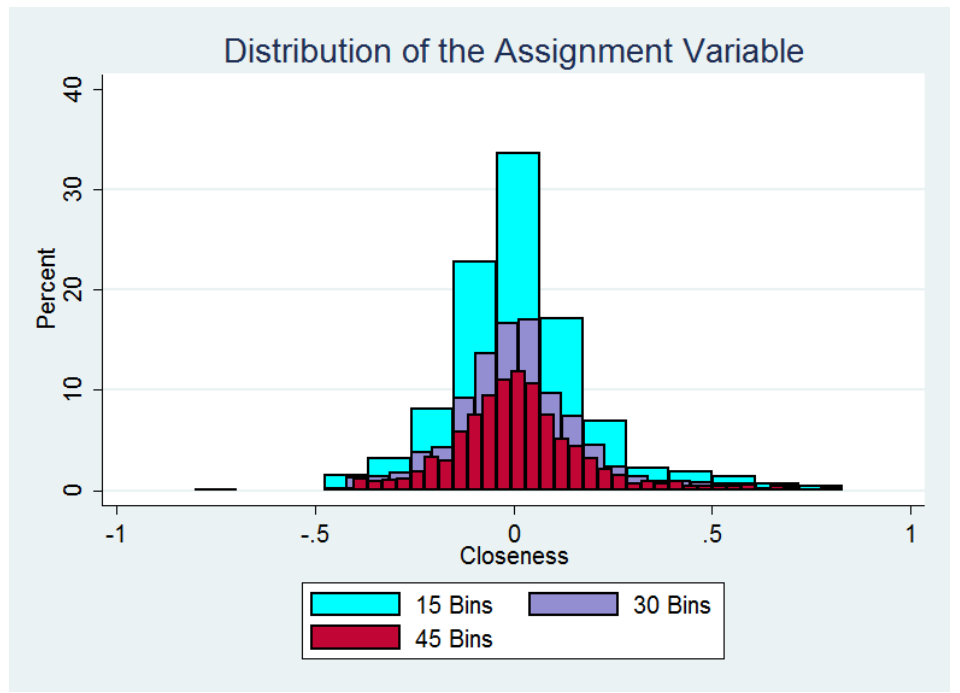


Table 15: Means by Divided versus Unified Government (Full Sample)

\begin{tabular}{|c|c|c|c|}
\hline Variable & $\begin{array}{l}\text { Unif. Govt. } \\
\text { Mean }\end{array}$ & $\begin{array}{l}\text { Div. Govt. } \\
\text { Mean }\end{array}$ & $\begin{array}{l}\text { ttest } \Delta \\
\text { p value }\end{array}$ \\
\hline Reform Dummy & 0.2014 & 0.2503 & 0.0254 \\
\hline Broad Reform Dummy & 0.2302 & 0.2811 & 0.0256 \\
\hline Broad Reform Count Variable & 0.5079 & 0.6457 & 0.0784 \\
\hline Narrow Reform Dummy & 0.1568 & 0.1951 & 0.0546 \\
\hline Narrow Reform Count Variable & 0.2187 & 0.2696 & 0.1181 \\
\hline Reform Package (including contractive and expansive policies) & 0.0669 & 0.0940 & 0.2014 \\
\hline Reform Dummy Geographic Neighbors & 0.2181 & 0.2196 & 0.9136 \\
\hline Reform Dummy Population Size Neighbors & 0.2219 & 0.2263 & 0.7604 \\
\hline Share of AFDC/TANF Recipients in Pop. (Caseload) & 0.0290 & 0.0306 & 0.0797 \\
\hline \% Unemployed $(/ 1000)$ & 0.0060 & 0.0060 & 0.4856 \\
\hline Deflated Total State Revenue per Capita (/1000) & 2.0788 & 2.2430 & 0.0000 \\
\hline Unmarried Birth (per 1,000 unmarried women) & 28.599 & 28.984 & 0.4409 \\
\hline Maximum AFDC/TANF Benefit Level for a Family of $3(/ 1000)$ & 0.3465 & 0.3755 & 0.0000 \\
\hline Per Capita Income (/1000) & 22.143 & 23.067 & 0.0872 \\
\hline Population $(/ 1000000)$ & 5.2472 & 5.9231 & 0.0279 \\
\hline$\%$ Population Black & 10.878 & 9.9415 & 0.0581 \\
\hline \% Population Latino & 6.4043 & 7.0629 & 0.1550 \\
\hline$\%$ Population 65 or older & 12.421 & 12.406 & 0.8759 \\
\hline$\%$ Population 17 or younger & 26.303 & 26.021 & 0.0407 \\
\hline \% Immigrant Population & 1.6788 & 2.0732 & 0.0001 \\
\hline 90th/10th Ratio of Household Income & 7.9548 & 8.0187 & 0.3739 \\
\hline Governor Lame Duck (i.e. cannot be reelected) & 0.2950 & 0.2362 & 0.0106 \\
\hline Gubernatorial Election & 0.2820 & 0.2734 & 0.7134 \\
\hline Polarization Senate & 0.3077 & 0.3761 & 0.0000 \\
\hline Polarization House & 0.3190 & 0.3777 & 0.0000 \\
\hline \% Women in State Legislature & 17.433 & 18.933 & 0.0006 \\
\hline \% Democratic Votes in Last Presidential Election $(/ 1000)$ & 0.0442 & 0.0448 & 0.1750 \\
\hline Citizens Ideology (Berry et al. 1998) (/1000) & 0.0474 & 0.0500 & 0.0014 \\
\hline Democratic Seat Share in Senate & 0.5843 & 0.5436 & 0.0000 \\
\hline Democratic Seat Share in House & 0.5751 & 0.5478 & 0.0028 \\
\hline Government Ideology (Berry et al. 1998) (/1000) & 0.0493 & 0.0502 & 0.5223 \\
\hline Governor Party Dummy $(1=$ Democrat $)$ & 0.6273 & 0.4159 & 0.0000 \\
\hline $\mathrm{N}$ & 695 & 779 & 1474 \\
\hline
\end{tabular}

Notes: The first and second column give variable means for the group of unified and the group of divided governments meanings, and data sources, see the Data Appendix.

Table 16: Means by Divided versus Unified Government (5\% Closeness Sample)

\begin{tabular}{llcc}
\hline Variable & $\begin{array}{l}\text { Unif. Govt. } \\
\text { Mean }\end{array}$ & $\begin{array}{l}\text { Div. Govt. } \\
\text { Mean }\end{array}$ & $\begin{array}{l}\text { ttest } \Delta \\
\text { p value }\end{array}$ \\
\hline & & & \\
Reform Dummy & 0.2066 & 0.2863 & 0.0487 \\
Broad Reform Dummy & 0.2300 & 0.3105 & 0.0535 \\
Broad Reform Count Variable & 0.4883 & 0.6613 & 0.1605 \\
Narrow Reform Dummy & 0.1549 & 0.1976 & 0.2334 \\
Narrow Reform Count Variable & 0.1831 & 0.2823 & 0.0819 \\
Reform Package (including contractive and expansive policies) & 0.0800 & 0.0882 & 0.8341 \\
Reform Dummy Geographic Neighbors & 0.2417 & 0.2337 & 0.7624 \\
Reform Dummy Population Size Neighbors & 0.2402 & 0.2278 & 0.6314 \\
Share of AFDC/TANF Recipients in Pop. (Caseload) & 0.0298 & 0.0324 & 0.1006 \\
\% Unemployed (/1000) & 0.0058 & 0.0060 & 0.2620 \\
Deflated Total State Revenue per Capita (/1000) & 2.0997 & 2.1353 & 0.5301 \\
Unmarried Birth (per 1,000 unmarried women) & 28.765 & 27.455 & 0.1150 \\
Maximum AFDC/TANF Benefit Level for a Family of 3 (/1000) & 0.3611 & 0.3801 & 0.1436 \\
Per Capita Income (/1000) & 22.251 & 21.974 & 0.7551 \\
Population (/1000000) & 5.5576 & 6.3102 & 0.1492 \\
\% Population Black & 10.038 & 9.0870 & 0.2600 \\
\% Population Latino & 6.4436 & 6.4143 & 0.9725 \\
\% Population 65 or older & 12.380 & 12.565 & 0.2316 \\
\% Population 17 or younger & 26.115 & 26.089 & 0.9075 \\
\% Immigrant Population & 1.6561 & 1.8487 & 0.2867 \\
90th/10th Ratio of Household Income & 7.8632 & 7.8703 & 0.9516 \\
Governor Lame Duck (i.e. cannot be reelected) & 0.2300 & 0.1573 & 0.0475 \\
Gubernatorial Election & 0.1831 & 0.1734 & 0.7863 \\
Polarization Senate & 0.3749 & 0.3891 & 0.1562 \\
Polarization House & 0.3914 & 0.3894 & 0.8324 \\
\% Women in State Legislature & 18.948 & 18.077 & 0.2654 \\
\% Democratic Votes in Last Presidential Election (/1000) & 0.0441 & 0.0448 & 0.2837 \\
Citizens Ideology (Berry et al. 1998) (/1000) & 0.0485 & 0.0507 & 0.1027 \\
Democratic Seat Share in Senate & 0.5412 & 0.5587 & 0.2145 \\
Democratic Seat Share in House & 0.5396 & 0.5592 & 0.1333 \\
Government Ideology (Berry et al. 1998) (/1000) & 0.0504 & 0.0500 & 0.8597 \\
Governor Party Dummy (1 = Democrat) & 0.5915 & 0.3831 & 0.0000 \\
N & & & \\
& 213 & 248 & 461 \\
\hline
\end{tabular}

Notes: The sample is restricted to observations where the election result determining whether government would be divided or unified was decided by a 5 percentage points or smaller vote/seat margin. For details, see the RDD Appendix. The first and second column give variable means for the group of unified and the group of divided governments respectively. The third column gives $\mathrm{p}$ values from a two sided group mean comparison $\mathrm{t}$ test. For details on coding, variables meanings, and data 


\section{D.4 Results}

This subsection presents the results from a short RDD analysis. The low number of observations makes a parametric approach preferable over a nonparametric approach. The regressions therefore fit a polynomial in the collapsed assignment variable to estimate the treatment effect at the boundary. Restricting the analysis to close elections (which is a nonparametric technique) makes the analysis semiparametric. In that sense the approach could be best described as a semiparametric RDD with multiple interdependent assignment variables.

Appendix Table 17 shows the results. Columns (1) to (4) have the welfare reform dummy as dependent variable. Columns (5) to (8) have the lagged reform dummy as dependent variable, i.e. the right part of the table presents a placebo test where no treatment effect of divided government is expected (since the current form of government should not affect reform adoption in the past). Each triple of numbers (coefficient, standard error, R squared) shows the result of one RDD regression of reform on divided government. Columns (1) to (4) and (5) to (8) add a polynomial of degree 0 to 3 in the assignment variable as control function. The first two rows look at the full sample, the third and fourth restrict the sample to observations where the collapsed treatment assignment variables takes values of $5 \%$ or smaller, i.e. to close elections (where the distance to the treatment boundary is 5 percentage points or less). Restricting the sample mimicks a nonparametric approach. A fully nonparametric approach is infeasible because of the small number of observations. While the first and the third row regressions do not include any controls besides the polynomial control function, the second and the fourth row regressions include state and year fixed effects, state specific linear trends, and the full set of demographic conditions (lagged by one year) as controls. If the RDD is indeed quasi-random and the identifying assumptions are fulfilled, controls are not necessary for identification and should not change much in terms of results. However, it has been argued that including them can increase the precision of the estimates and may be especially worthwhile in the case of a low number of observations (Hoxby (2000), Pettersson-Lidbom (2008), and Pettersson-Lidbom (2012)).

Table 17: Divided Government and Reform (RDD Analysis)

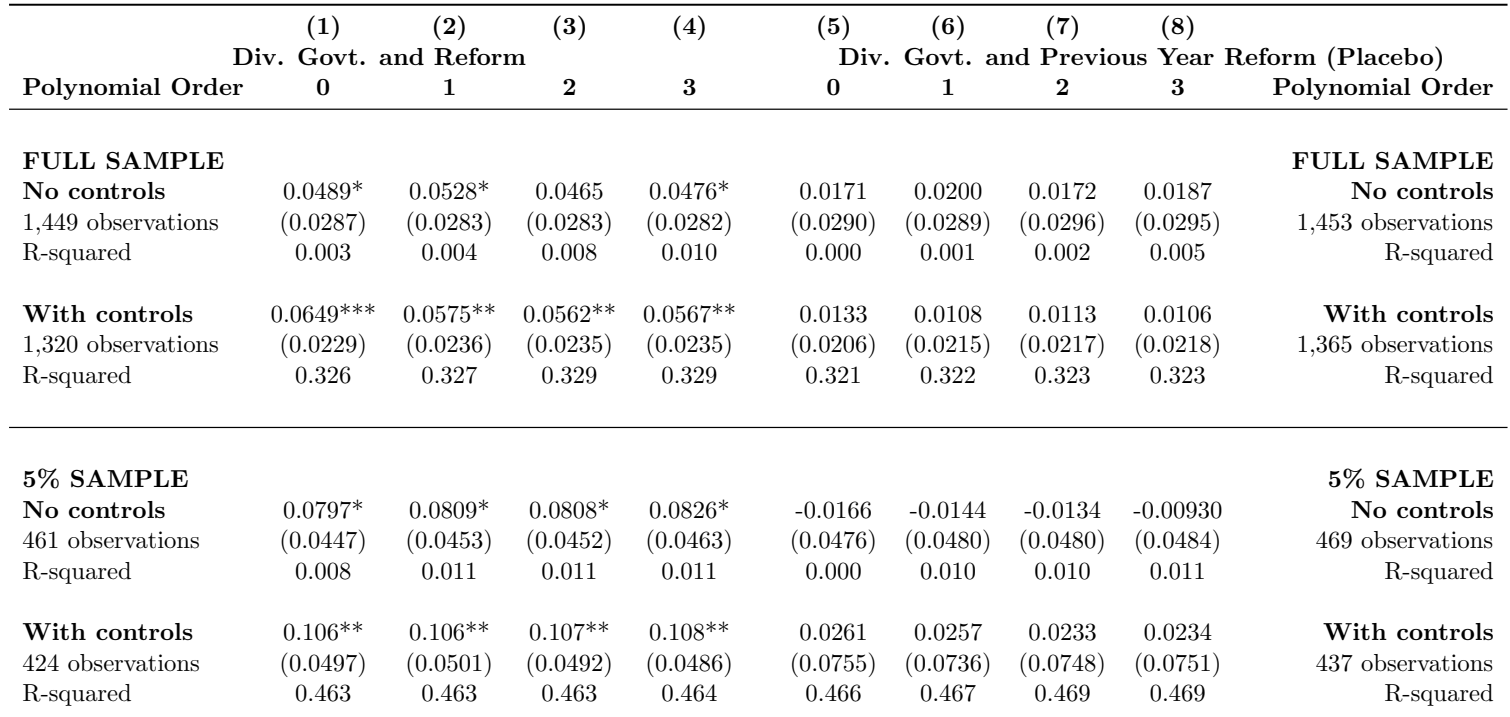

Notes: The left part of this table shows the effect of divided government on reform. The right part of this table shows the effect of divided government on previous year's reform (placebo test where no effect is expected). Each triple of numbers (coefficient, standard error, R-squared) refers to one estimation. The method of analysis is parametric RDD (with polynomials in the assignment variable from orders 0 to 3 ) conducted either using the full sample or a sample restricted to cases where the closeness of a hypothetical treatment assignment change from divided to unified government or vice versa was ex post 5 percentage points or smaller (i.e. Whe the closict where the assignis ex post a diference of 5 percentage points or less in th gube

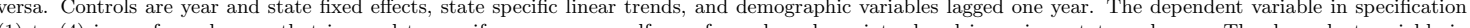
(1) to (4) is a reform dummy that is equal to one if one or more welfare reforms have been introduced in a given state and year. The dependent variable in specifications (5) to (8) is the same variable lagged. Divided Government is a dummy that is equal to one when either the majority of the state's lower legislative chamber or the majority of the state's upper legislative chamber is from another party than the governor. For details regarding any of the variables, see the Data Appendix. Robust standard errors clustered at the state level are shown in parentheses. ${ }^{* * *} \mathrm{p}<0.01,{ }^{* *} \mathrm{p}<0.05$ and ${ }^{*} \mathrm{p}<0.1$.

As can be seen from the table, the RDD in columns (1) to (4) largely confirms the results from the panel data regressions presented before. There is a significantly positive effect of divided government on the adoption of reforms. Although the size of the RDD coefficients is not directly comparabe to the results from the analysis before since the RDD estimates the effect at the treatment boundary, the 
analysis nevertheless clearly supports the finding that divided governments are more likely to reform than unified governments. Adding controls to the RDD seems to increase precision, but as expected does not change the overall picture. The placebo check in columns (5) to (8) also works out: It seems reasonable to assume that the current form of government affects current and possibly future reform adoption, but cannot affect reform adoption in the past. If the empirical design is valid, one should therefore not find any effect of divided government on previous year reform. This is indeed that the right part of Appendix Table 17 shows: The esimated coefficients are rather small and none of them is significant at any conventional level.

\section{E Data}

Note that most of the data come directly from Bernecker and Gathmann (2013). Summary statistics are provided in Table 1, means of variables by divided versus unified government in Appendix Table 15 and Appendix Table 16.

\section{E.1 Divided Government Variables}

Divided Government is a dummy that is equal to one when either the majority of the state's lower legislative chamber or the majority of the state's upper legislative chamber is from another party than the governor. "Divided Government at Federal Level" is defined equivalently for the US federal government. Split Branch is equal to one if the governor in a state is confronted with majorities of the opposing party in both legislative chambers. Split Legislature is equal to one if the majorities in the two legislative chambers in a state are from opposing parties. All divided government measures exclude cases where the governor is party-independent (neither a Democrat nor a Republican) and cases where a legislative chamber is itself split, i.e. having the same amount of Democratic and Republican seats. The variables "Divided Government with past..." are defined on the level of governments (instead of years) and condition on the past type of government, e.g. "Divided Government with past Republican Unified Government" refers to a divided government that replaces a Republican unified government which has been in office before. The two variables "New Divided Government via General Elections" and "New Divided Government via Midterm Elections" are also defined on the level of governments. The former is a dummy that is equal to one if there was a change from unified to divided government and the governor was up for election in the most recent election. The latter is a dummy that is equal to one if there was a change from unified to divided government and the governor was not up for election in the most recent election. Note that the change from a unified Democratic to a divided government typically occurs via general elections (often via a Republican governor being elected). The change from a unified Republican to a divided government, on the other hand, usually occurs via midterm elections (via the Republicans losing the majority in one of the legislative chambers). These patterns result in highly significant and sizeable correlations between "Divided Government with past Democratic Unified Government" and "New Divided Government via General Elections" (corr $=0.75$ ) on the one hand and "Divided Government with past Republican Unified Government" and "New Divided Government via Midterm Elections" (corr $=0.4)$ on the other hand. This is also the reason why means and standard deviations of these dummy variables are very similar. A careful inspection reveals, however, that the variables are in fact not only theoretically, but also empirically not the same. The underlying data for the divided government variables have been obtained from Klarner (2003) and Klarner's webpage (http://www.indstate.edu/polsci/klarnerpolitics.htm).

\section{E.2 Welfare Reform Variables}

The reform dummy used as dependent variable in most of the analyses in this paper is constructed from different data sources. From 1978 to the Welfare Reform in 1996, the reform dummy is equal to one if a state has filed a waiver application at the federal level in a given state and year. This includes waiver applications rejected by the federal level and also applications referring to only some counties of the state. The data on waivers have been obtained from Lieberman and Shaw (2000) and cross-checked using Koerper (1996) and Crouse (1999). The waiver data do not go back to the period before 1978. However, states have in principle been in a position to file waiver applications already since 1962. But since waivers did not become popular before the late 1970s, the data starting in 1978 nevertheless capture most relevant welfare waiver activity in the states. 
With the implementation of the Welfare Reform in 1996, welfare waivers became irrelevant. Within some federal guidelines, states were now free to set their own welfare policy rules. After 1996, the reform dummy is equal to one if a state changed its welfare policy rules. Information on welfare policy changes at the state level is obtained from the Welfare Rules Database maintained by the Urban Institute (Urban Institute (2012)). This database contains the states' welfare rules from 1996 onwards. The basis of the data are the plans of the states (approved by governor and legislature). Data collection is done via states' caseworker manuals and policy updates that are sent to them during the year. TANF administrators of the states verify the data on the policy rules before publication. This makes the data most complete and uptodate and "one of the most reliable sources on TANF social policies available" (Fellowes and Rowe (2004), p. 365).

Table 18: Welfare Policy Rules used for Definition of Reforms (1996-2010)

\begin{tabular}{|c|c|}
\hline Policy Rule & Description of Rule \\
\hline Family Cap (1) & Benefits do not increase if an additional child is born in family while receiving benefits. \\
\hline \multicolumn{2}{|l|}{ Work Requirements (4) } \\
\hline Hours Requirement & Minimum \# of hours a recipient must participate in work-related activities. \\
\hline Work upon Enrollment & Work requirements apply at application stage, approval stage or upon benefit receipt (or later). \\
\hline Time Limit to Work & Work at least 20 hours per week in an unsubsidized job after a certain period of benefit receipt. \\
\hline Exemptions to Work Requirements & Number of exemptions state allows to hours requirements (for older, pregnant, ill beneficiaries, for examples). \\
\hline \multicolumn{2}{|l|}{ Time Limits (4) } \\
\hline Duration of Lifetime Limit & Maximum \# of months an assistance unit can receive benefits over the lifetime. \\
\hline Intermittent Time Limit & \# months time an assistance unit can receive benefits without interruption. \\
\hline Benefit Reduction after Intermittent Time Limit & How much benefits are reduced (adult portion or benefit unit) when assistance unit hits the intermittent time limit. \\
\hline Time Limit Extensions & Whether the state offers any type of time limit extension. \\
\hline \multicolumn{2}{|l|}{ Sanctions (5) } \\
\hline Severity of Worst Sanction & How much benefits are reduced under worst sanction for non-compliance with work requirements. \\
\hline Duration of Worst Sanction & Length of most severe sanction for not complying with work requirements. \\
\hline Reapply & Whether the unit has to reapply after worst sanction for non-compliance has been imposed. \\
\hline Severity of Initial Sanction (from 1999 onwards) & How much benefits are reduced for first non-compliance with work requirements. \\
\hline Duration of Initial Sanction (from 1999 onwards) & Length of first sanction for not complying with work requirements. \\
\hline
\end{tabular}

The baseline reform dummy is based on changes in 14 highly relevant policy rules in the areas family caps, work requirements, time limits, and sanctions. The detailed rules are given in Appendix Table 18. The broad reform dummy is based on these 14 and 10 additional policy rules ( 24 rules in total). These additional rules cover eligibility tests and requirements and are presented in Appendix Table 19. See Bernecker and Gathmann (2013) for further coding details regarding the policy rules. The narrow reform dummy captures only contractive reforms, is based on only a subset of the baseline rules, and in some cases also uses stricter codings (to cover significant reforms only; see modification in parentheses): family caps, hours requirement (of at least 30 hours), work upon enrollment, reapply, duration of lifetime limit (below 60 months), benefit reduction after intermittent time limit (removal of whole family benefit). The narrow reform dummy also includes "mandatory job search prior to TANF eligibility" and "worst sanction is removal of full family benefit" as two additional policy rules ( 8 rules in total). The reform package dummy, finally, is only defined for 1996 to 2010 and is equal to one when at least one contractive and at least one expansive policy rule change occur in the same year. The reform package dummy is based on the baseline set of 14 rules (but uses a dummy whether the first sanction is the removal of the full family benefit instead of the two rules referring to severity and duration of the initial sanction since the latter two are only available from 1999 onwards).

For the analysis of spillover effects, the reform dummy in neighboring states is relevant. The Reform Dummy Geographic Neighbors is the average of the Reform Dummy for all geographically adjacent states. For each state, it thus measures the share of neighboring states that have conducted a reform in a given year. The Reform Dummy Population Size Neighbors does the same, but considers states with a similar population size instead of geographic neighbors. For this second measure, the states are divided into ten different bands according to their population size in 1978. The ten bands are (CA NY TX PA IL), (OH MI FL NJ MA), (NC IN GA VA MO), (WI TN MD LA MN), (WA AL KY CT SC), (IA OK CO AZ OR), (MS KS AR WV NE), (UT NM ME RI HI), (ID NH MT NV SD), (ND DE VT WY AK).

Data on the Maximum AFDC/TANF Benefit Level for a Family of Three (with no income) which is used as a control in parts of the analysis has been obtained from Han et al. (2009) who made their data available at http://www.nber.org/workfamily/ and updated using data provided in the Welfare Rules Database maintained by the Urban Institute (Urban Institute (2012)) available at 
Table 19: Additional Welfare Policy Rules Used for Broad Definition of Reforms (1996-2010)

\begin{tabular}{|c|c|}
\hline Policy Rule & Description of Rule \\
\hline \multicolumn{2}{|l|}{ Asset Test for Eligibility (2) } \\
\hline Monetary Assets Allowed & Monetary value of maximum unrestricted assets a family may have and still be eligible for cash benefits. \\
\hline Vehicle Exemption & Monetized value of vehicle exemptions that are not counted towards the assets test for applicants. \\
\hline \multicolumn{2}{|l|}{ Eligibility Requirements (2) } \\
\hline Eligibility of Pregnant Women & Dummy for whether a state allows pregnant women with no other children to be eligible. \\
\hline Eligibility of Minor Parent & Dummy for whether a minor parent (under age 18 and never married) is eligible to head a TANF assistance unit. \\
\hline \multicolumn{2}{|c|}{ Eligibility for Two-Parent Families (2) } \\
\hline Two-Parent Working Hours Limit & Limit on working hours a state imposes on two-parent households to stay eligible. \\
\hline Two-Parent Waiting Period & Whether a state requires the principal wage earner to have worked for a specified time period for eligibility. \\
\hline \multicolumn{2}{|l|}{ Additional Requirements (4) } \\
\hline School Requirement & Whether a state mandates children to attend school or maintain a certain GPA for the assistance unit to receive cash benefits. \\
\hline School Bonus & Whether a state offers financial incentives to assistance units when children meet state set performance or attendance standards. \\
\hline Immunization Requirement & Whether a state mandates children in the assistance unit to meet standard immunizations for children. \\
\hline Other Health Requirement & Whether a state requires adults and children to get regular health checkups. \\
\hline
\end{tabular}

http://anfdata.urban.org/wrd/tables.cfm (Table II.A.4).

\section{E.3 Demographic Variables}

The Share of AFDC/TANF Recipients in Population (Caseload) is taken from Moffitt (2002) until 1998 and updated to 2010 using the Statistical Abstract (United States Census Bureau (2011)). The \% Unemployed is also taken from Moffitt (2002) until 1998 and updated to 2010 using the website of the Bureau of Labor Statistics. Per Capita Income is taken from the website of the Bureau of Economic Analysis and deflated by the urban consumer price index (with year 2002=100). The variables Population, \% Black Population, \% Population 65 or older, \% Population 17 or younger are all taken from the Statistical Abstract (United States Census Bureau (2011)). The \% Population Latino has been obtained from several websites of the US Census Bureau: http://www.census.gov/popest/data/historical/1980s/state.html (for the 1980s), http://www.census.gov/popest/data/state/asrh/1990s/st_race_hisp.html (for the 1990s), and http://www.census.gov/popest/data/intercensal/state/state2010.html (for the 2000s). The \% Immigrant Population refers to legal immigrants admitted by state of intended residence (then divided by state population) and is taken from Fang and Keane (2004) for 1970 to 2002 and updated using the Yearbook of Immigration Statistics (U. S. Department of Homeland Security (2011)) for 2011 and for previous years (available at http://www.dhs.gov/yearbook-immigrationstatistics). Unmarried Birth refers to the \% of all births to unmarried women per 1,000 unmarried women aged 15-44 years by state of residence. For the years 1992 to 2003, the data are avaiable from Table 8.3 in the TANF Annual Reports to Congress. For the remaining years, data have been obtained from the Centers for Disease Control and Prevention and the National Vital Statistics System (available at http://www.cdc.gov/nchs/data_access/vitalstats/VitalStats_Births.htm and http://205.207.175.93/VitalStats/) and completed and cross-checked using data available at the National Bureau of Economic Research: http://www.nber.org/data/vital-statistics-natality-data.html. The 90th/10th Ratio of Household Income (90th percentile divided by 10th percentile of all positive household incomes) is calculated from the March Current Population Survey (Center for Economic and Policy Research (2012)).

\section{E.4 Political Variables}

The \% Democratic Votes in Last Presidential Election is taken from the Statistical Abstract (United States Census Bureau (2011)) and updated using Leip (2012). The Democratic Seat Share in Upper House and the Democratic Seat Share in Lower House are calculated based on information about the number of legislators by party and the total number of seats of state legislatures obtained from Klarner (2003) and Klarner's webpage (http://www.indstate.edu/polsci/klarnerpolitics.htm). This is also the source for the Governor Party variable. Polarization of Senate and House are calculated as 0.5-|democratic seat share0.5. The \% Women in State Legislature is obtained from the website of the Center for American Women and Politics (Center for American Women and Politics (2012)). Governor Lame Duck is equal to one if 
the incumbent governor cannot run for reelection. Gubernatorial Election is a dummy equal to one if a gubernatorial election took place this year. Both variables are obtained from List and Sturm (2006) until 2000 and updated using Leip (2012). Citizens Ideology and Government Ideology are calculated by Berry et al. (1998) from ideology ratings of the state's congressional delegation, the American for Democratic Action (ADA) rating and the AFL/CIO's Committee on Political Education (COPE) rating. Berry et al. assign an ideology rating to the citizens of each congressional district using a weighted average of the score of the congressional member and his or her election opponent, weighting the scores according to the number of votes they received. Zero denotes the most conservative and 100 the most liberal. They then generate a state-wide measure by averaging over all congressional districts. The measure of government ideology is constructed by assigning to the governor and major party delegations in the legislature the ratings of the members of Congress from their party. Updates of these ideology data are available at http://www.bama.ua.edu/ rcfording/stateideology.html.

\section{E.5 Public Finance Variable}

The variable Deflated Total State Revenue Per Capita is calculated by using data on state revenues (obtained from Paul Ehmann at the US Census Bureau (http://www.census.gov/govs/state/)) and dividing those numbers by the state population (see demographic variables explained above) and by the urban consumer price index (with years 1982-1984=100) provided by the US Bureau of Labor Statistics at ftp://ftp.bls.gov/pub/special.requests/cpi/cpiai.txt. 